\title{
Development of Biopolymers as Binders for Feed for Farmed Aquatic Organisms
}

\author{
Marina Paolucci ${ }^{1}$, Adele Fabbrocini², \\ Maria Grazia Volpe ${ }^{3}$, Ettore Varricchio ${ }^{1}$ and Elena Coccia ${ }^{1}$ \\ ${ }^{1}$ Department of Biological, Geological and \\ Environmental Sciences, University of Sannio \\ ${ }^{2}$ C.N.R. National Research Council, I.S.MAR \\ ${ }^{3}$ C.N.R. National Research Council, I.S.A. \\ Italy
}

\section{Introduction}

Diets for aquatic animals are numerous. They differ from species to species and may change to meet varied nutritional requests during the life cycle, and may be designed for larvae, juveniles, adults and breeders. In this review we will focus on a particular aspect of aquaculture feed represented by binders. Binders can be liquids or solids with the capacity of forming bridges, coatings or films that make strong inter-particle bonding. Binders are used to improve feed manufacture and to stabilize diets in water. Differently from feed for livestock, feed for aquaculture requires an adequate level of processing to guarantee good stability in water, long enough for animals to consume it. For this reason the role of binder is crucial in determining variable levels of firmness adequate to specific feeding behaviour. Although the problem of feed stability is far more crucial with crustaceans than with fish, some fish are benthic and small pellets that sink rapidly to the bottom where they can be located and recognized by the chemoreceptors of the fish are highly sought. Usually commercial feed for fish is stable after extrusion and binders are not requested to improve water stability. In some recent experiments binders are included in practical diets for fish to generate firmer feces when emitted into water to reduce pollution (Brinker, 2007). Among crustaceans crayfish are slow feeders with a characteristic tendency, that they share with prawns and shrimps, to manipulate food using mouth appendages before ingestion (Holdich, 2002). Thus, in aquatic animal feed preparation, to stabilize feed pellets and to ensure minimum nutrient leaching and disintegration appear to be crucial. Feed stability is considered a crucial requirement also in the echinoculture. Indeed, sea urchin are grazers and need time to eat the offered feed, so that it must remain intact for several days, in order to limit the loss of nutrients and to make rearing structure management easier (Caltagirone et al., 1992; Mortensen et al., 2004; Pearce et al., 2004). In addition, prepared diets frequently lead to poor gonad quality in terms of texture, firmness, colour and taste (Pearce et al., 2002a), that means low marketability of the product. For these reasons research focused on the selection of appropriate binders to ensure consistence to the experimental feed must take into account their effects not only on feed stability but also on gonad yield and sensorial quality. Since a binder may not be optimal for all species, and even for the same species the 
feeding behaviour may change during the life cycle numerous studies have been conducted to evaluate the type of binder, the optimal level of inclusion and its effect on growth and digestibility in different species of aquatic animals.

In this review, feed will be examined from the point of view of binder selection, method of preparation, assessment of water stability and nutrient leaching and with reference to the binder effect on growth and utilization by the animal. Purposefully, this review does not deal with diet composition for aquatic animals. Research on nutritional requirements of aquatic animals is a highly competitive field in constant and rapid evolution and it is outside the scope of the present article. For readers interested in this topic we suggest referring to the numerous reviews and books available.

\section{Feed binders}

Food is the material which, after ingestion by the animal, is capable of being digested absorbed and utilized. However, not all components of food are digestible. The main components of food are as follows:

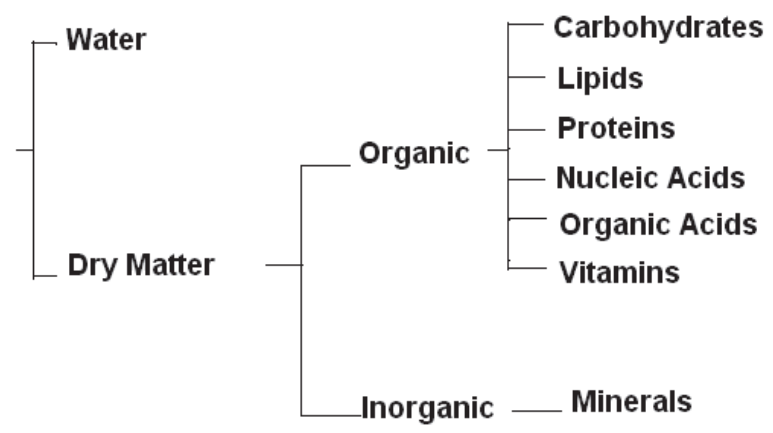

Nutrients are components of food which can be utilized by the animal either as energy sources or for metabolic processes. The energy source components are the proteins, lipids and carbohydrates, while the vitamins and minerals are need to be present in small quantities in the feed for metabolism and life maintenance. There are various factors influencing the choice of feed for farmed fish. Of these, the economic factor is usually given precedence. Feeds and feeding can represent about half the operating costs in farming. Other important factors in manufacturing aquatic animal feeds are the stability of the feed in water and its acceptability. Inclusion of a binder is a necessity to ensure water stable feed. Many substances have been selected for their binding properties. Numerous natural binders have been employed to manufacture hard pellets with the purpose of increasing water stability with a concomitant decrease in nutrient loss. Some of these binders, such as wheat gluten or starches, have a nutritive value for the animals, while others are inert raw materials without nutritional value (Sinha et al., 2011). More than 50 organic and inorganic binders have been employed in feed industry (Kalian \& Morey, 2009). Among natural binders examined and employed by researchers, biopolymers are by far the most studied. The most common biopolymers derive mainly from plants and animals of marine and agricultural origin. Examples are cellulose, starch, pectin, chitin and proteins such as casein, whey, collagen and soy proteins. In this review we will focus on the most employed for aquatic feed. 
According to De Silva and Anderson (1995) binders can be grouped in three different classes:

1. binders of protein origin

2. carbohydrate source binders

3. binders with no nutritional value

From a nutritional perspective a protein binder may be more appropriate than a carbohydrate binder for a carnivorous species, while the contrary holds true for a herbivorous species. Carbohydrates are often included in crustacean artificial diets for their protein-sparing effect (Shiau \& Peng, 1992; Rosas et al., 2000). According to the theory of Minimal Total Discomfort (Forbes, 2001), the ingestion of carbohydrates of vegetal origin brings about a protein sparing effect in wild animals and therefore enhances growth without wasting proteins. In fact, the intake of food has physiological consequences via physical (e.g. distension) and chemical (e.g. glucose) stimulation of receptors in the viscera and, in the longer term, by changes in signals from adipose tissue (e.g. leptin), integrated by the CNS (Paolucci, 2010). These consequences are associated with the sensory properties of the food such that repeated exposure to a food generates a conditioned acceptance or rejection reflex with the physiological consequences of eating as the unconditioned stimulus (US) and the sensory characteristics of the food as the conditioned stimulus (CS). Such learnt preferences and aversions occur throughout the animal kingdom, from nematodes to human beings, with much of the research being carried out with insects, laboratory animals and farm animals. Preferences for and aversions to particular foods are manifested in non-random choices between two or more foods on offer but also influence the quantity eaten when only one food is available. These considerations have been developed into a theory of Minimal Total Discomfort (Forbes, 2001) which proposes that an animal experiments with the amount eaten per day, and its selection between different foods, until the total of the signals generated from excesses or deficiencies of food components is minimised. Changes in food composition and/or nutrient requirements can therefore be matched by appropriate changes in intake and selection.

\subsection{Carbohydrates}

Polysaccharides are natural biopolymers formed by high molecular weight carbohydrates (Aspinall, 1982). They are biodegradable, biocompatible and non-toxic polymers showing peculiar physical-chemical properties and environmentally sustainable features. The specific macromolecular structures, characterized by the presence of several polar functional groups, allow polysaccharides to retain significant amounts of water or biological fluids, thus providing the formation of hydrogels, i.e. three-dimensional, reliable networks, able to become water resistant throughout chemical or physical phenomena, such as gel formation, retrogradation process, $\mathrm{pH}$-changing and cross linking processes (Coviello et al., 2007). The molecular diversity of carbohydrates allows a large array of functions of great significance. In the food industry, polysaccharides play important roles as phytocolloid as well as emulsifying agents (Farris et al., 2009). Non-digestible carbohydrates are insoluble, like cellulose, or soluble, like pectin, gum, $\beta$-glucan, mucilage, algal polysaccharides (Atkins, 1985; Clark \& Ross-Murphy, 1987). Technologically, they are needed for altering the texture and consistency of foods (Drochner et al., 2004) and show properties that make them 
suitable for use in increasing food shelf-life (Volpe et al., 2010). Carbohydrates represent the most abundant biological molecules, covering a large array of fundamental roles in living things: from the reserve and transport of energy, (starch and glycogen), to the development of structural components (cellulose in plants, chitin in animals), to the linking between intercellular walls (hemicellulose) (Kennedy \& White, 1983). The high molecular weight carbohydrates derived, are known as polysaccharides. They may be viewed as condensation polymers in which carbohydrates have been glycosidically joined, with the elimination of molecules of water, according to the empirical equation

$$
\mathrm{n} \mathrm{C}_{6} \mathrm{H}_{12} \mathrm{O}_{6} \rightarrow\left(\mathrm{C}_{6} \mathrm{H}_{10} \mathrm{O}_{5}\right) \mathrm{n}+(\mathrm{n}-1) \mathrm{H}_{2} \mathrm{O}
$$

The different macromolecular structures and chemical compositions of polysaccharides are responsible for the large array of their physical and biochemical applications. A wide range of polysaccharides, such as agar, alginate, chitin and pectin are able to hydrate in cold and hot water, thus giving rise to both viscous solutions or dispersions and gels. The great interest with these polysaccharides in aquatic animal feed is strictly related to their gelling properties.

\subsubsection{Agar}

Agar is a polymer extracts from agarophyte, a seaweed, typically a red alga (Usov, 1998). It consists of at least two separate polymers that could be fractionated into agarose andagaropectin. Agarose is high in molecular weight and low in sulphate. Agaropectin is low in molecular weight and high in sulphate. Agarose is the gelling fraction of agar. Agarose is a linear polymer structure consisting of alternating D-galactose and 3,6 anhydroL-galactose as shown in Fig. 1.

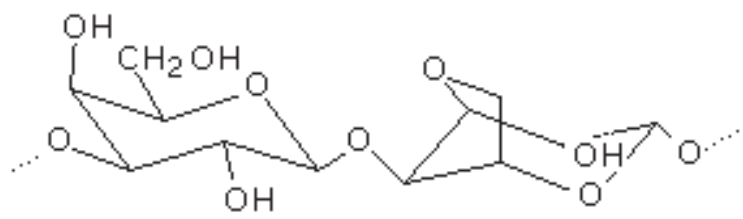

Fig. 1. Molecular structure of agarose

The diverse forms of agarose determine the physicochemical characteristics of agar such as gelling and melting temperature and reactivity. Agar is a mixture of agarose and agaropectin in variable proportions depending on the original raw material and the manufacturing process employed. Agar gelation occurs only by its agarose content and is produced exclusively by hydrogen bonds. Agar does not need any other substance to gel, and therefore it has an enormous potential in applications such as foodstuff ingredient, for biotechnology uses, for cell and tissue cultures or as a support for electrophoresis or chromatography. Agarose produces "physical gels" which means that these aqueous gels are formed only by the polymer molecules united solely by hydrogen bonds. Due to this unique gelling property, such gels hold in the interior network a great amount of water which can move freely through the macroreticulum. Each molecule maintains its structure in complete independence so that the process is not a polymerization but a simple electrostatic attraction. Agar is actually a very complex polysaccharide and varies 
considerably depending on the source. Back in 1991, eleven different agarose structures were identified in different agar bearing weeds depending on gender, species environmental conditions and time of the year. Moreover, agar may be modified by substitution of sulphate, pyruvate, uronate or methoxyl groups. Modern alkali treatment methods tend to increase the level of anhydrous bridging in the molecule with subsequent improvement of gel strength.

\subsubsection{Alginate}

Sodium Alginate is the sodium salt of alginic acid, a complex mixture of oligo-polymers, polymannuronic acid (MM), polyguluronic acid (GG) and a mixed polymer (MG) where sequences like GGM and MMG co-exist (Smidsrod et al., 1966). The mannuronic acid forms $\beta$ (1-4) linkages, so that M-block segments show linear and flexible conformation. The guluronic acid instead gives rise to a (1-4) linkages, introducing a steric hindrance around the carboxyl groups; for this reason the G-block segments provide a folded and rigid structural conformation, responsible for a pronounced stiffness of the polymer. $M$ and $G$ blocks of the alginic acid salts are reported in Fig. 2.

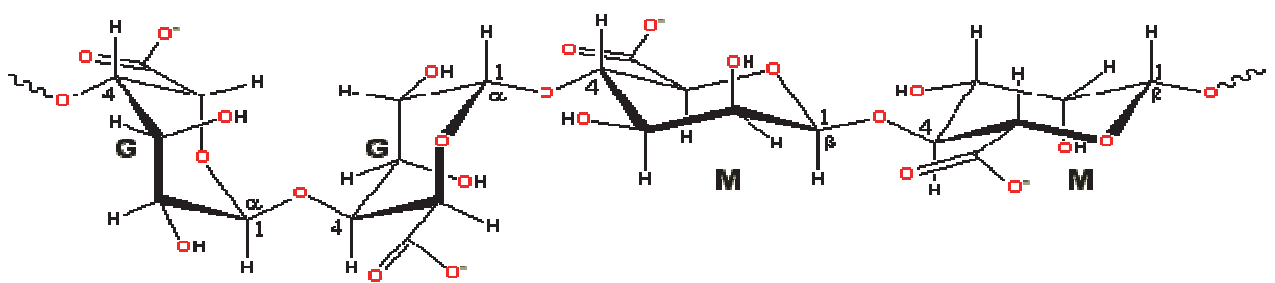

Fig. 2. Molecular structure of alginic acid

In a water solution and in the presence of divalent cations, such as calcium ions, the peculiar buckled backbone of $G$ segments gives rise to water insoluble gel due to the strong interactions between the divalent cations and the COO- groups of the base residual of guluronic acid. Cations can be trapped in a stable, continuous and thermo-irreversible threedimensional network, whose conformation is typical of an "egg box" (Grant et al., 1973; Grasdalen, et al., 1981) as shown in Fig. 3.

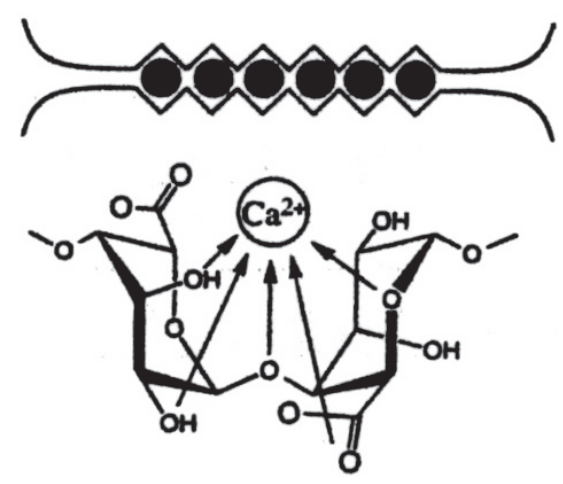

Fig. 3. Alginic acid "egg box" structure. 
As a consequence, calcium alginate gel does not dissolve in water. Nevertheless, a rehydration process occurs, allowing the gel to swell and to modulate the releasing of entrapped substances.

\subsubsection{Pectin}

Pectin is a polysaccharide extracted from plant cell walls and is used in many industrial applications as a thickener or gelling agent (Stephen, 1983). Pectin is a polymer of agalacturonic acid with a variable number of methyl ester groups (Fig. 4).

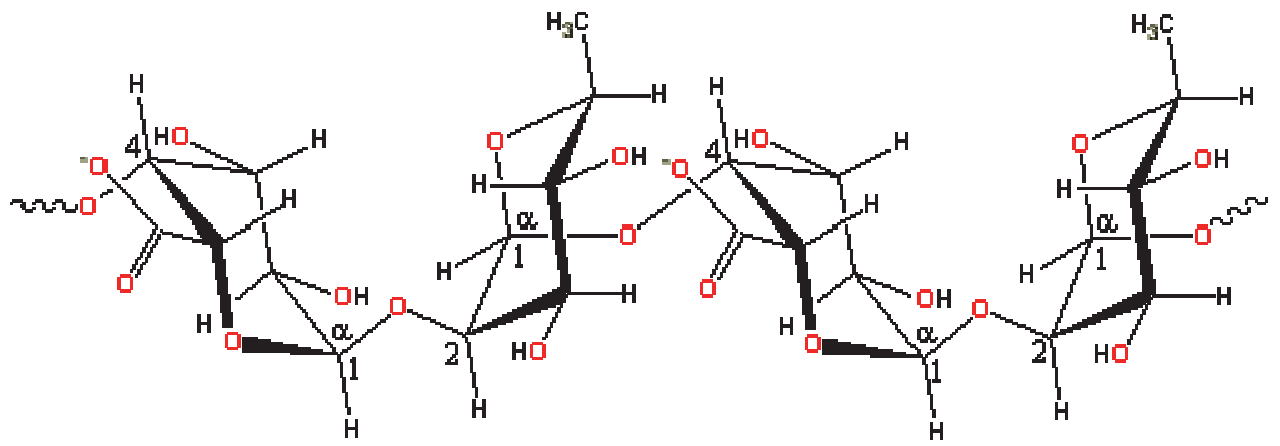

Fig. 4. Molecular structure of pectin

Generally, pectin does not possess an exact structure, therefore, it does not adopt a straight conformation in solution, but is extended and curved with a large amount of flexibility. The methylation of the carboxylic acid groups forms methyl esters which are much more hydrophobic and consequently have a different effect on the structuring of the surrounding water. The properties of pectin depend on the degree of esterification, which is normally about $70 \%$. Gel strength increases with increasing $\mathrm{Ca}^{2+}$ concentration but it reduces with temperature and acidity increase $(\mathrm{pH}<3)$. In the absence of added cations, low methoxypectin ( $\sim 35 \%$ esterified) gels by the formation of cooperative "zipped" associations at low temperatures $\left(\sim 10^{\circ} \mathrm{C}\right)$ forming transparent gels. This hydrogen-bonded association is likely to be similar to that of alginate. High methoxyl-pectin ( $>43 \%$ esterified, usually $\sim 67 \%$ ) gels by the formation of hydrogen-bonding and hydrophobic interactions in the presence of acids ( $\mathrm{pH} \sim 3.0$, to reduce electrostatic repulsions) and sugars (for example, about $62 \%$ sucrose by weight, to reduce polymer-water interactions). While the gel formed by low methoxyl-pectin results as being thermoreversible and not stable in water, the gel formed by high methoxyl-pectin is thermoirreversible mostly in the presence of high content of sugar (sucrose) and at low $\mathrm{pH}$. In these conditions, the process of re-hydration of pectin gel is partially avoided by the firm hydrophobic structural network.

\subsubsection{Chitosan}

Chitosan is a cationic carbohydrate biopolymer derived from chitin, the second most abundant polysaccharide present in nature after cellulose. The main sources of chitin are the shell wastes of shrimps, lobsters and crabs (Johnson \& Peniston, 1982). Upon the removal of most of the acetyl groups of chitin by treatment with strong alkali, chitosan yields. So 
chitosan may be considered as a family of linear binary copolymers of $(1 \rightarrow 4)$-linked 2acetamido-2-deoxy- $\beta$-D-glucopyranose (GlcNAc) and 2-amino-2-deoxy- $\beta$-D-glucopyranose (GlcN) (Fig.5).

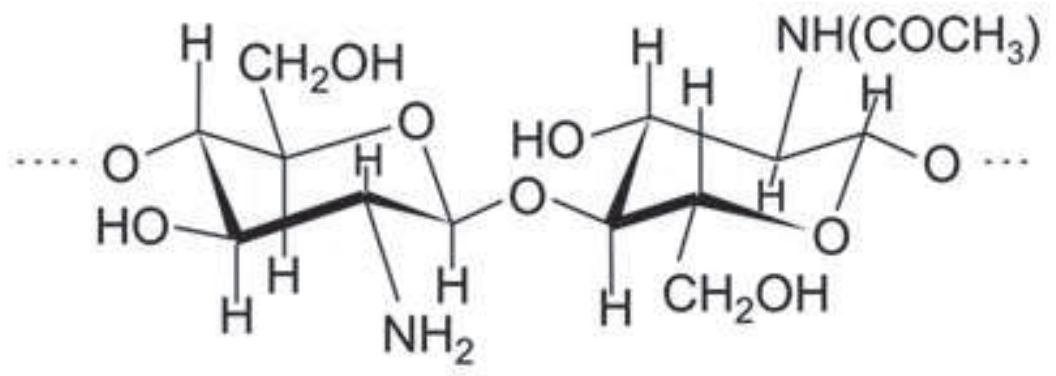

Fig. 5. Molecular structure of chitosan

Chitosan has a very diversified range of established and potential applications related to its polycationic properties, which are unique among polysaccharides and natural polymer in general (No \& Meyers, 1995). It is well known that chitosan may complex with certain metal ions and this property is used for removal of traces of heavy metals or radio isotope in waste water. Another well documented application of chitosan is as a cholesterol-lowering agent but the much more controversial use of it, is as a weight reducing agent. It is also used as a potential vehicle for orally administered controlled-release drugs. So this material is proposed for preparing micro spheres and microcapsules (El-hefian et al., 2011). These are only few of the applications of chitosan. Although chitin is insoluble in most solvents, the properties of chitosan are related to its polyelectrolyte polymeric carbohydrate character. It is insoluble in water while it readily dissolves in dilute solutions of most organic acids such as acetic, citric, tartaric acids. Chitosan gel does not undergo a substantial swelling process when placed in water; it is instead stable because the polymer itself results as being insoluble in water (Cerver et al., 2004).

\subsubsection{Carrageenan}

Carrageenan is the hydrocolloid obtained from some red seaweeds by extraction with water or aqueous alkali (Murano et al., 1992; Kalia, 2005). Carrageenan consists chiefly of potassium, sodium, calcium, magnesium, and ammonium sulfate esters of galactose and 3,6 -anhydrogalactose copolymers. These hexoses are alternately linked $\alpha-1,3$ and $\beta-1,4$ in the polymer(Fig. 6). The threemain copolymers in the hydrocolloid are designated kappacarrageenan (k-carrageenan), iota-carrageenan ( $\mathrm{l}$-carrageenan) and lambda-carrageenan $(\lambda$ carrageenan). K-carrageenan is mostly the alternating polymer of D-galactose-4-sulfate and 3,6-anhydro-D-galactose. I-carrageenan is similar, except that the 3,6-anhydrogalactose is sulfated at carbon 2. Between k-carrageenan and $\mathrm{l}$-carrageenan there is a continuum of intermediate compositions differing in the degree of sulfation at carbon 2 . In $\lambda$-carrageenan, the alternating monomeric units are mostly D-galactose-2-sulfate (1,3-linked) and Dgalactose-2,6-disulfate (1,4-linked). The ester sulfate content for carrageenan ranges from 18 to $40 \%$. In addition, carrageenan contains inorganic salts that originate from the seaweed and from the process of recovery of the extract. Carrageenan is recovered by either alcohol precipitation, or drum drying, or freezing. Primary differences which influence the 


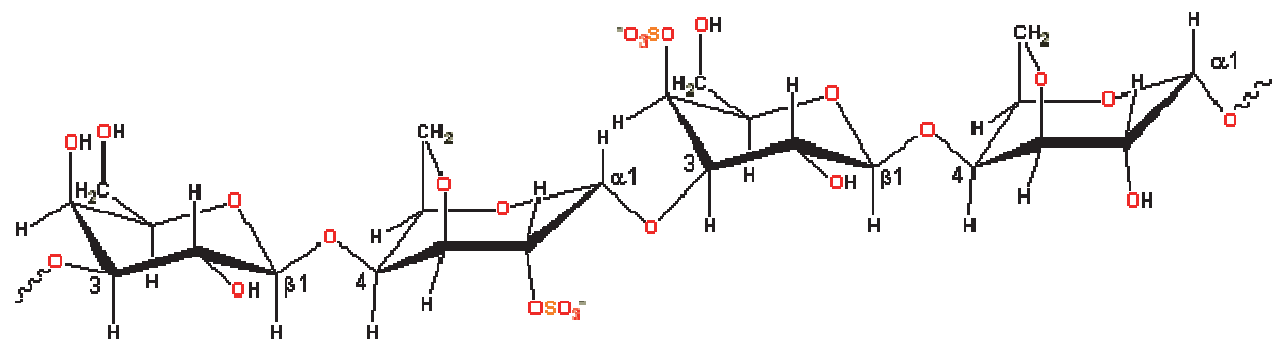

Fig. 6. Molecular structure of carrageenan

properties of $\mathrm{k}$-, $\mathrm{l}$ - and $\lambda$-carrageenan are the number and the position of the ester sulfate groups on the repeating galactose units (Kennedy \& White, 1983). Higher levels of ester sulfate lower the solubility temperature of the carrageenan and produce lower strength gel, or contribute to gel inhibition.

The comparative properties of the three types of carrageenan are reported in Table 1.

Kappa carrageenan
Soluble in hot water.
The addition of potassium
ions induces the formation of
a durable, brittle gel; it also
increases the gelling and
melting temperatures.

Strong, rigid gel, some syneresis, forms helix with $\mathrm{K}+$ ions. $\mathrm{Ca}++$ causes helices to aggregate and the gel to contract and become brittle.

Slightly opaque gel. Becomes clear with sugar.

Approximately $25 \%$ ester sulfate and 34\% 3,6-AG.

Compatible with water miscible solvents.

Insoluble in most organic solvents.

Typical use levels -0.02 to $2.0 \%$.

Iota carrageenan
Dilute solutions exhibit
thixotropic characteristics.
Soluble in hot water; sodium
iota carrageenan is soluble in
cold and hot water.

The addition of calcium ions will induce the formation of a durable, elastic gel, and increase gelling and melting temperatures.

Elastic gels, forms helix with $\mathrm{Ca}++$. Limited aggregation contributes to elasticity, no syneresis.

Clear gel.

Freeze/thaw stable.

Insoluble in most organic solvents.

Approximately 32\% ester sulfate and 30\% 3,6-AG.

Typical use levels -0.2 to $2.0 \%$.

\section{Lambda carrageenan}

Free flowing, non-gelling pseudo-plastic solutions in water.

Partially soluble in cold water, fully soluble in hot water.

No gel, random distribution of polymer chains.

Range from low to high viscosity.

Addition of cations has little effect on viscosity.

Compatible with water miscible solvents.

Insoluble in most organic solvents.

Stable over a wide range of temperatures, including freeze/thaw cycles.

Soluble in $5 \%$ salt solution, hot or cold.

Approximately $35 \%$ ester sulfate and little or no 3,6-AG.

Typical use level -0.1 to $1.0 \%$.

Table 1. Comparative properties of types of carrageenan 


\subsubsection{Carboxymethylcellulose}

Carboxymethylcellulose (CMC) is a derivative of cellulose formed by its reaction with alkali and chloroacetic acid. The CMC structure is based on the $\beta$-(14)-D-glucopyranose polymer of cellulose (Fig. 7).

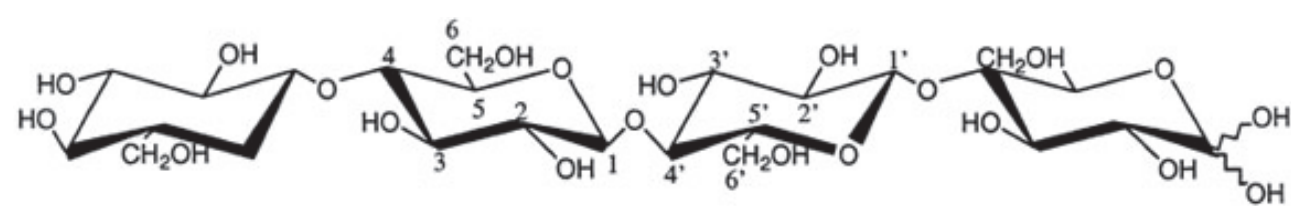

Fig. 7. Molecular structure of carboxymethylcellulose.

CMC molecules are shorter than native cellulose with uneven derivatization giving areas of high and low substitution. Substitutions are mostly 2-O- and 6-O-linked, followed in order of importance by 2,6-di-O- then 3-O-, 3,6-di-O-, 2,3-di-O- lastly 2,3,6-tri-O-linked. It appears that the substitution process is slightly cooperative (within residues) rather than a random process, which gives slightly higher than expected unsubstituted and trisubstituted areas. CMC molecules are highly extended (rod-like) at low concentration, while at higher concentration the molecules overlap and coil up and then entangle, to become a thermoreversible gel. Both increasing ionic strength and reducing $\mathrm{pH}$ decrease the viscosity as they cause the polymer to become more coiled. CMC dissolves rapidly in cold water and is mainly used for controlling viscosity without gelling. As its viscosity drops during heating, it may be used to improve the volume yield during baking by encouraging gas bubble formation. Its control of viscosity allows its use as thickener, and phase or emulsion stabilizer (for example, with milk casein), and suspending agent. CMC can be also used for its water-holding capacity as this is high even at low viscosity particularly when used with Ca2+ salt (Arisz et al., 1995).

\subsubsection{Guar gum}

Guar has been cultivated in India since centuries. India accounts for $80 \%$ of the total guar produced in the world. Historically, guar has been an important source of nutrition for humans as well as animals. Guar gum (galactomannan) is a high molecular weight carbohydrate derived from the natural seed of guar plant (Cyampopistetragonolobus). Structurally, guar gum is a polysaccharide consisting of a mannose backbone with a galactose side chain. The galactose is randomly placed on the mannose backbone with an average ratio of 1:2 galactose to mannose. The polymeric structure of guar gum containing numerous hydroxyl groups, has long since been exploited by industry (Goldstein et al., 1973). In Fig. 8 the guar gum chemical structure is reported.

The most important property of guar gum is its ability to hydrate rapidly in cold or hot water to attain uniform and very high viscosity at relatively low concentration. Another advantage associated with guar gum is that it provides full viscosity even in cold water. Although guar gum is one of the most cost-effective stabilizers and emulsifiers, its applications in food industry are numerous, due to its capacity to enhance texture, mouth feel, and to control crystal formation due to superior water-binding properties (CastilloGarcia et al., 2005). It is inert in nature and it is resistant to oil, greases, and solvents. It also has excellent synergy with several other hydrocolloids, particularly xanthan gum (Ahmed et al., 2005). It has a very high viscosity even when very little is used. 


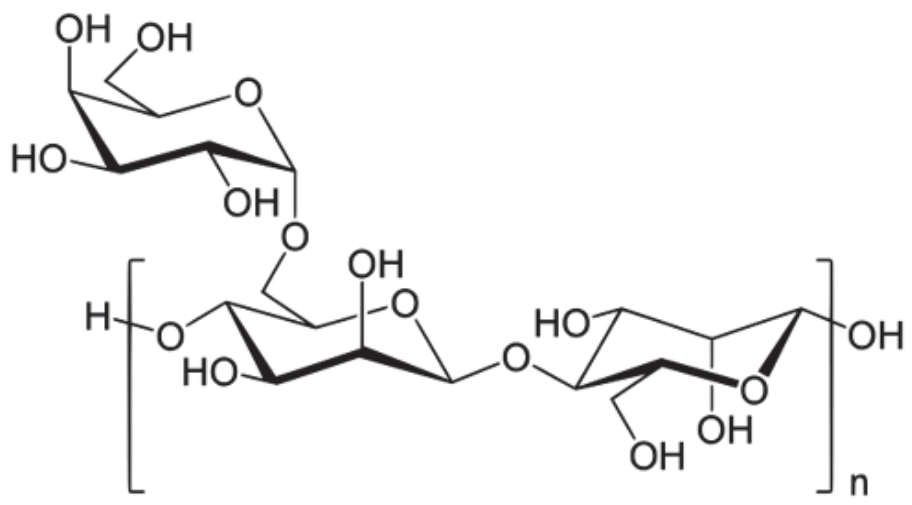

Fig. 8. Molecular structure of guar gum

\subsection{Proteins}

Among proteins, the mostly widely used as feed binders are urea formaldehyde, wheat gluten and gelatin. Gelatin-based binders are a good alternative to gluten and urea formaldehyde. Gelatin and gluten have the advantage of being fully digestible and contain proteins (De Muylder et al., 2008), however, gluten employment may have some drawbacks due to its antigenicity (Shewry, 2009).

\subsubsection{Gelatin}

Gelatin is a mixture of water-soluble proteins derived from collagen by hydrolysis. The protein fraction consists almost entirely of amino acids. These amino acids are joined by amide linkage to form a linear polymer ranging from 15,000 to 250,000 Mw. Gelatin is particularly attractive for forming hydrogel packaging because it is relatively inexpensive and biodegradable, and its structure enables multiple combinations of molecular interactions (Farris et al., 2009). There are two types of gelatins which are characterized by their mode of manufacture. Type A gelatin ( $\mathrm{pH} 3.8-6.0$; isoelectric point 6-8) is derived by acidic hydrolysis of pork skin and contributes to increasing the plasticity and elasticity to the blend. Type B gelatin ( $\mathrm{pH}$ 5.0-7.4; isoelectric point 4.7-5.3) is derived by basic hydrolysis of bones and animal skin and contributes to giving high gel strength to the blend. Various purity grades of gelatin are sold commercially in the form of translucent sheets, granules, or powders. Gelatin is practically odorless and tasteless. It is insoluble in acetone, chloroform, ethanol (95\%), ether, and methanol. It is soluble in glycerin, acids, and alkalis, although strong acids or alkalis cause it to precipitate. It swells and softens in water, gradually absorbing 5 to 10 times its own weight in water. It solubilizes in hot water. Upon cooling to $35-40{ }^{\circ} \mathrm{C}$, it forms a jelly or gel. At temperatures $\geq 40{ }^{\circ} \mathrm{C}$, the system exists as a sol. A gel of higher viscosity is formed in alkaline media as compared with acid media (Robinson et al., 1975). Since it is a protein, gelatin exhibits chemical properties characteristic of proteins (e.g., gelatin is hydrolyzed by most of the proteolytic systems to yield its amino components). Gelatin reacts with acids and bases, aldehydes and aldehydic sugars, anionic and cationic polymers, electrolytes, metal ions, plasticizers, preservatives, and surfactants. 


\section{Feed manufacture}

Feed used in small-scale experiments is usually prepared by simple operations. Ingredients are ground and mixed by hand or by extrusion at room temperature (cold-extrusion). Grinding of feed ingredients is a crucial operation since pellets made with finely ground ingredients will be more durable and hard (Lim \& Cuzon, 1994). Cold extrusion has the advantage of preserving the nutritional properties of the diet in comparison to extrusion at high temperature. Although extrusion technology is widely employed in the production of aquaculture feeds (Chevanan et al., 2009) the high temperature and pressure may negatively affect the nutritional value of ingredients (Cuzon et al., 1994; Watanabe, 2002). On the other hand, heat-extrusion of macro algae based prepared feed makes carbohydrates more digestible compared with fresh algae ones, leading to better gonad yields in reared sea urchins (Akiyama et al., 2001).

Binders usually employed at a concentration to reach a final percentage ranging from 1 to $10 \%$ are dissolved in either warm or hot water. As the temperature decreases and the solution turns into a gel, diet ingredients are added (Ruscoe et al., 2005; Volpe et al., 2008; Simon, 2009). Diversely, binders are added in their powdery form to the diet ingredients, mixed and hot water is poured on the mixture, then stirred thoroughly to obtain a dough (Orire et al., 2010). Some binders such as zein are first dissolved in ethanol due to their water insolubility (Genodepa et al., 2004; Johnston \& Johntson, 2007). The outcome is a microbound diet. Pellets are obtained by passing the dough in a mincer to form noodles that are cut in pieces of few $\mathrm{mm}$, or the dough is spread on a tray and cut into pieces. Alternatively, the mixture is put in a marumerizer and spheroid fed particles are produced (Liu et al., 2008). Steam pellets can be obtained using a laboratory pellet mill (Palma et al., 2008). Pellets are either stored at low temperature (from $4^{\circ} \mathrm{C}$ to $-20^{\circ} \mathrm{C}$ ) until use or dried in order to decrease the moist content and then stored (Ruscoe et al., 2005). The former can be defined as "moist pellets" and the latter as "dry pellets". A third type of pellet can be defined as "gelatinous pellets" and are obtained by mixing the dietary ingredients with oil (Johnston \& Johnstson, 2007; Liu et al., 2008). Pellets can also be coated with binders, leading to what is then termed a microcoated diet (Bautista et al, 1989).

\section{Assessment of feed stability in water}

Water stability of feed is of paramount importance in the manufacture of aquaculture diets. Water stability is greatly influenced by the properties of binders, although the ingredients themselves have a direct influence on the characteristics of the binders (Dominy \& Lim, 1991). Durazo-Beltran and Viana (2001) report difficulty in bonding the constituents of fish silage to generate pellets for abalone farming, probably because of the high content of hydrolyzed protein. Although the water stability of aquatic feed is a major concern of the aquaculture industry, there is no standard method to determine feed water stability. It is usually estimated by the method of dry matter weight loss, according to which a certain amount of feed, usually in the form of pellets, is placed in a water containing beaker and allowed to stay for a variable length of time with occasional shaking. Pellets are then decanted and dried. Variability can be found in literature about the amount of water in which pellets are placed, temperature, time intervals, methods in pellet drying after incubation in water (Ruscoe et al., 2005; Johnston \& Johnston, 2007; Palma et al., 2008; Orire et al., 2010). A slight modification of the dry matter weight loss is suggested by the 
American Feed Industry Association (AFIA 1999 in Liu et al., 2008). According to the AFIA water stability is expressed as a percentage of pellets retained on a wire mesh sieve after immersion in a shaking water bath for a period on time after which the pellets are retrieved and dried. Obaldo et al. (2002) developed three methods for measuring the water stability of shrimp pelleted feeds: a static method, a horizontal method and a vertical shaking method. Several factors were taken into consideration (water and pellet agitation, direction of agitation, water temperature, salinity, leaching container, filtration medium) among which temperature and water salinity influenced the rates of dry matter retention the most. Higher water temperatures and lower levels of salinity produced more leaching and lower dry matter retention. In general, the three methods appeared to provide an accurate and precise means of determining the water stability of shrimp feeds. The employment of water shaking is particularly interesting inasmuch as it may mimic the actual indoor and outdoor culture conditions and can be usefully adjusted to variable conditions.

Water stability is expressed as a percentage of immersed diet weight/initial sample weight (Liu et al., 2008; Orire et al., 2010), or as percent loss of dry matter (\%LDM) calculated as percent difference in sample weight (minus the initial diet moisture) after reweighing (Fagbenro \& Jauncey, 1995; Johnston \& Johnston, 2007), or as percentage of dry matter remaining $(\% \mathrm{DMR})$ calculated with the formula $\% \mathrm{DMR}=$ Wo $\mathrm{X}(1-\mathrm{M})-\mathrm{Wt} /$ Wo $\mathrm{X}(1-\mathrm{M}) \mathrm{X}$ 100 where $W_{0}=$ pellet weight as-fed, $\mathrm{Wt}=$ weight after immersion and drying, and $\mathrm{M}=$ moisture content of diet as a proportion (Ruscoe et al., 2005).

Caltagirone et al. (1992) suggest a subjective parameter, to be taken into account together with the \%LDM, in the evaluation of binder efficiency, that is the consistency of food, defined according to the following scale: 1) inconsistency (feed completely disintegrates on removal from the water; 2) weak consistency (feed partially disintegrates on removal from the water; 3 ) good consistency (feed does not disintegrate on removal from the water but disaggregates after the application of a weak pressure; 4) very good consistency (feed does not disintegrate on removal from the water and resists weak pressure). According to these evaluation parameters Caltagirone et al. (1992) evaluated six binding agents after 48 hours of water immersion: agar-agar, cellulose, CMC, guar gum, gelatine and sodium alginate. Cellulose and CMC were unsuitable as binders even at strong concentrations; sodium alginate retained a good consistency but showed a high loss of weight, while guar gum, gelatine and agar-agar appeared to be good binders in terms of pellet stability. Pearce et al. (2002b) tested prepared feed with different binders (gelatin, guar gum, sodium alginate, and corn starch), evaluating their effectiveness according to the above described methodology up to 216 hours of immersion in sea water. Guar gum and starch-based pellets became inconsistent after 24 hours of immersion; sodium alginate retained a good consistence for up to 48 hours, while gelatine remained firm and intact even after 216 hours in sea water. Again with the same evaluation procedure Mortensen et al. (2004) tested the stability of a pellet in which gelatine from fishskin was strengthened with the enzyme transglutaminase. Feed retained a good consistency for up to 7 days in sea water and the loss in dry matter, even increasing with time, reached $17.6 \%$, with respect to $60.1 \%$ of the salmon feed used as control.

In our laboratory, we adopted a rather different methodology, according to which pellet water stability was analyzed by monitoring the diameter of the released particles in water over progressive time intervals, employing a Low Angle Laser Light Scattering Technique. (Volpe et al., 2008; Coccia et al., 2010; Fabbrocini et al., 2011). The diameter of particles 
released by pellets are continuously monitored over time, thus providing a time-course indication about the water stability as a function of the released particle diameter inasmuch as pellets that disaggregate into small particles are less stable in water than pellets that disaggregate into particles of a larger diameter. According to this evaluation methodology the binder capacity of two algal polysaccharides (alginate and agar) and one polysaccharide from fruit (pectin) revealed that pectin showed better water stability than alginate and agar (Volpe et al., 2008). When a coating was added to the microbound pellets water stability was improved. Indeed, microbound pellets disaggregated into particles of a derived diameter almost twice as large as pellets manufactured without coating (Coccia et al., 2010). Palma et al. (2008) report that pellets without binder, but with a microcoat of lignosol behaved less well in water than pellets made with lignosol as a binder, indicating that the presence of an internal binder is necessary to provide firmness to the feed. Using the Low Angle Laser Light Scattering Technique 3\% and 6\% agar-based round pellets specifically designed for sea urchin feeding, proved to have good water stability with a significant increase in the diameter of the released particles recorded only after 5 days of immersion in sea water for $3 \%$ agar- and 6 days for $6 \%$ agar-based pellets (Fabbrocini et al., 2011).

Due to the ample variability in feed ingredients, percentage of binders included and manufacture technology, it is impossible to come to the conclusion that a certain binder is better than another with respect to its water stability performances. Moreover, experimental outcomes are reported in literature as relative, that is a binder behaving better than another under specific conditions, making impossible an objective evaluation of binder performances. Nonetheless, in table 2, literature data on feed water stability are reported.

\begin{tabular}{|c|c|c|c|c|}
\hline $\begin{array}{c}\text { WATER } \\
\text { STABILITY TEST }\end{array}$ & $\begin{array}{c}\text { MAX TIME } \\
\text { INTERVAL } \\
\text { CONSIDERED }\end{array}$ & $\begin{array}{l}\text { \% OF BINDER } \\
\text { EMPLOYED }\end{array}$ & OUTCOME $^{1}$ & REFERENCE \\
\hline $\begin{array}{l}\text { Dry matter } \\
\text { weight loss }\end{array}$ & $10 \mathrm{~min}$ & $\begin{array}{l}\text { 3\% CMC, corn } \\
\text { starch, guar gum, } \\
\text { wheat gluten }\end{array}$ & $\begin{array}{l}\text { CMC, guar gum, } \\
\text { wheat gluten }>\text { corn } \\
\text { starch }\end{array}$ & $\begin{array}{l}\text { Fagbenro } \\
\text { and Jauncey, } \\
1995\end{array}$ \\
\hline $\begin{array}{l}\text { Dry matter } \\
\text { weight loss }\end{array}$ & $2 \mathrm{~h}$ & $2 \%$ agar, lignin & Lignin>agar & $\begin{array}{l}\text { Palma et al., } \\
2008\end{array}$ \\
\hline $\begin{array}{l}\text { Dry matter } \\
\text { weight loss }\end{array}$ & $12 \mathrm{~h}$ & $\begin{array}{l}5 \% \text { carrageenan } \\
3 \% \text { zein, agar } \\
2 \% \text { alginate, gelatin }\end{array}$ & $\begin{array}{l}\text { Alginate,gelatin> } \\
\text { carrageenan, zein, } \\
\text { agar }\end{array}$ & $\begin{array}{l}\text { Johnston and } \\
\text { Johnston, } \\
2007\end{array}$ \\
\hline $\begin{array}{l}\text { Dry matter } \\
\text { weight loss }\end{array}$ & $12 \mathrm{~h}$ & $\begin{array}{l}10 \% \text { Wheat flour } \\
2 \% \text { Whole cassava } \\
\text { meal, dried molasses, } \\
\text { agar, Langobin }{ }^{\circ}\end{array}$ & $\begin{array}{l}\text { Wheat flour }>\text { whole } \\
\text { cassava meal }>\text { dried } \\
\text { molasses }>\text { agar }> \\
\text { langobin }\end{array}$ & $\begin{array}{l}\text { Seixas Filho } \\
\text { et al., 1997a }\end{array}$ \\
\hline $\begin{array}{l}\text { Dry matter } \\
\text { weight loss }\end{array}$ & $24 \mathrm{~h}$ & $\begin{array}{l}0.5-2.5 \% \text { Agar, } \\
\text { Alginate, } \\
\text { Carrageenan } \\
\end{array}$ & All effective at $0.5 \%$ & $\begin{array}{l}\text { Durazo- } \\
\text { Beltran and } \\
\text { Viana, } 2001 \\
\end{array}$ \\
\hline $\begin{array}{l}\text { Dry matter } \\
\text { weight loss }\end{array}$ & $48 \mathrm{~h}$ & $\begin{array}{l}\text { Agar-agar, carboxyl- } \\
\text { methyl-cellulose } \\
\text { (CMC), guar gum, } \\
\text { gelatin, sodium } \\
\text { alginate, cellulose }\end{array}$ & $\begin{array}{l}\text { Agar-agar, gelatin, } \\
\text { guar gum }>\text { sodium } \\
\text { alginate }>\text { CMC, } \\
\text { cellulose }\end{array}$ & $\begin{array}{l}\text { Caltagirone } \\
\text { et al., } 1992\end{array}$ \\
\hline
\end{tabular}




\begin{tabular}{|c|c|c|c|c|}
\hline \begin{tabular}{|c|} 
WATER \\
STABILITY TEST
\end{tabular} & $\begin{array}{l}\text { MAX TIME } \\
\text { INTERVAL } \\
\text { CONSIDERED }\end{array}$ & $\begin{array}{l}\text { \% OF BINDER } \\
\text { EMPLOYED }\end{array}$ & OUTCOME $^{1}$ & REFERENCE \\
\hline $\begin{array}{l}\text { Dry matter } \\
\text { weight loss }\end{array}$ & $168 \mathrm{~h}$ & $\begin{array}{l}\text { Fish-skin } \\
\text { gelatin }+0.13 \% \\
\text { transglutaminase } \\
\text { (TG) }\end{array}$ & $\begin{array}{l}\text { Gelatin + TG > } \\
\text { commercial salmon } \\
\text { feed }\end{array}$ & $\begin{array}{l}\text { Mortensen et } \\
\text { al., } 2004\end{array}$ \\
\hline $\begin{array}{l}\text { Dry matter } \\
\text { weight loss }\end{array}$ & $216 \mathrm{~h}$ & $\begin{array}{l}\text { Guar gum, gelatin, } \\
\text { sodium alginate, } \\
\text { corn starch }\end{array}$ & $\begin{array}{l}\text { Gelatin }>\text { sodium } \\
\text { alginate }>\text { guar gum, } \\
\text { corn starch }\end{array}$ & $\begin{array}{l}\text { Pearce et al., } \\
2002 b\end{array}$ \\
\hline $\begin{array}{l}\text { Dry matter } \\
\text { retention }\end{array}$ & $30 \mathrm{~min}$ & $\begin{array}{l}7 \% \text { starch } \\
2 \% \text { carrageenan, } \\
\text { CMS, alginate, } \\
\text { gelatin }\end{array}$ & $\begin{array}{l}\text { Carrageenan }> \\
\text { alginate }>\text { gelatin }> \\
\text { CMS }\end{array}$ & $\begin{array}{l}\text { Liu et al., } \\
2008\end{array}$ \\
\hline \begin{tabular}{|l|} 
Dry matter \\
remaining after \\
immersion in \\
water
\end{tabular} & $180 \mathrm{~min}$ & $\begin{array}{l}3 \text { and } 5 \% \\
\text { carrageenan, } \mathrm{CMC} \text {, } \\
\text { agar, gelatin }\end{array}$ & $\begin{array}{l}\text { Carrageenan, } \\
\text { CMC> agar, gelatin }\end{array}$ & $\begin{array}{l}\text { Ruscoe et al., } \\
2005\end{array}$ \\
\hline $\begin{array}{l}\text { Variation in } \\
\text { weight after } \\
\text { soaking in } \\
\text { water } \\
\end{array}$ & 24 hours & $\begin{array}{l}10 \% \text { Gelatin } \\
30 \% \text { alginate }\end{array}$ & Alginate $>$ gelatin & $\begin{array}{l}\text { Valverde et } \\
\text { al., } 2008\end{array}$ \\
\hline $\begin{array}{l}\text { Variation in } \\
\text { weight after } \\
\text { soaking in } \\
\text { water }\end{array}$ & 24 hours & $\begin{array}{l}2 \% \text { alginate plus } 1 \% \\
\text { sodium } \\
\text { hexametaphosphate } \\
\text { or D-gluconic acis as } \\
\text { sequestrants } \\
9 \text { and } 13 \% \text { agar } \\
6 \text { and } 15 \% \text { gelatin } \\
20 \% \text { agar/gelatin } \\
\text { mixture }\end{array}$ & $\begin{array}{l}\text { Agar/gelatin }> \\
\text { agar }> \\
\text { alginate>gelatin }\end{array}$ & $\begin{array}{l}\text { Knauer et } \\
\text { al., } 1993\end{array}$ \\
\hline \begin{tabular}{|l|} 
Long Angle \\
Laser Light \\
Scattering \\
Technique \\
\end{tabular} & 24 hours & $\begin{array}{l}2.5 \% \text { Agar, alginate, } \\
\text { pectin }\end{array}$ & $\begin{array}{l}\text { Pectin>agar, } \\
\text { alginate }\end{array}$ & $\begin{array}{l}\text { Volpe et al., } \\
2008\end{array}$ \\
\hline \begin{tabular}{|l|} 
Long Angle \\
Laser Light \\
Scattering \\
Technique \\
\end{tabular} & 24 hours & $\begin{array}{l}1 \% \text { chitosan, pectin, } \\
\text { agar, alginate }\end{array}$ & $\begin{array}{l}\text { Chitosan, pectin> } \\
\text { agar, alginate }\end{array}$ & $\begin{array}{l}\text { Coccia et al., } \\
2010\end{array}$ \\
\hline $\begin{array}{l}\text { Long Angle } \\
\text { Laser Light } \\
\text { Scattering } \\
\text { Technique }\end{array}$ & \begin{tabular}{|l|}
$96 h$ \\
$144 h$
\end{tabular} & $3 \%$ agar, $6 \%$ agar & $\begin{array}{l}\text { No differences } \\
\text { agar } 6 \%>\text { agar } 3 \%\end{array}$ & $\begin{array}{l}\text { Fabbrocini et } \\
\text { al., } 2011\end{array}$ \\
\hline
\end{tabular}

${ }^{1}$ The reported outcome refers to the maximum time interval tested . > means that the binder(s) on the left perform better that the binder(s) on the right. * a commercial binder.

Table 2. Effect of binders on feed water stability. 


\section{Assessment of nutrient leaching}

Binder type may affect feed stability in water, and by leaching of attractant molecules may determine attractiveness of microbound diets. Partridge and Southgate (1999) report that leaching increased with decreasing binder concentration. O'Mahoney et al. (2011) in a study aimed at investigating the characteristics of new substances to be employed as binders for abalone farming, found no dry matter leaching after up to 4 days of water immersion of feed containing glucomannan-xanthan gum. In spite of the importance of assessing nutrient leaching there is still no standard method to determine it. Some authors report nutrient leaching and dry matter loss after water immersion as synonyms. Other authors use instead different procedures to determine nutrient leaching such as radiolabelled substances included into the feed, internal markers, detection of specific nutrients, protein or lipid. Genodepa et al. (2007) included ${ }^{14} \mathrm{C}$-labelled rotifers in the feed and tested the effect of zein, agar, alginate and carrageenan on nutrient leaching. They report that leaching occurred primarily within the first 30 minutes of immersion and longer immersion periods (up to 240 min) only resulted in a very modest increase in leaching rates. The leaching rate of zeinbound diets was significantly lower than that of agar-, alginate- and carrageenan-bound diets. On the contrary, Fagbenro and Jauncey (1995) report that the leaching of total protein content was very low, after $10 \mathrm{~min}$ immersion in water of pellets made with $3 \% \mathrm{CMC}$, corn starch, guar gum or wheat gluten. Accordingly, Simon (2009) found no significant difference in chromic oxide (as internal standard) and nutrient concentrations after 1 hour immersion in water of pellets containing gelatine $(8 \%)$, alginate $(7 \%)$, or agar $(8 \%)$. Kovalenko et al. (2002) evaluated dietary water soluble vitamins riboflavin and thiamine levels before and after water immersion of feed containing $5.38 \%$ of alginate and report a substantially high loss of both vitamins after 90 min of immersion, with the greatest percent loss within 1 to 15 min interval. Falayi et al. (2006) evaluated total protein and lipid content in pelleted feed samples containing 10\% wheat grain starch and cassava tuber starch as both binding agents and carbohydrate source. They found that after 1 hour of water immersion protein retention dropped to about $80 \%$ while lipid retention was about $97-95 \%$.

\section{Binder effect on growth}

The relationship between the availability and composition of food and the growth rate of a given aquatic species is of a crucial importance for the optimization of the rearing conditions. In order to understand this relationship the main physiological processes of the organism (ingestion, assimilation, respiration, growth and reproduction) should be taken into account and evaluated by means of integrated models (Van der Meer, 2006). Theories of dynamic energy budgets (DEB) received great impetus in the last decades, against the previous prevalent static approach. Among the various models proposed, the Kooijman Krule DEB theory (Kooijman, 2001) is one of the most encompassing. As reported in Figure 9, this model assumes that a part of ingested food is assimilated, then it enters the reserves and therefore a part is spent for maintenance and growth (prioritary flux), while the rest is utilized for maturation and reproduction.

Being all DEB models relatively simple, they did not take into account species-specific physiological aspects of the single considered species, which therefore need to be considered each time. On the basis of these considerations and given that binders often account for a consistent part of a prepared pellet, the effect of these substances on the ingestion, digestion 


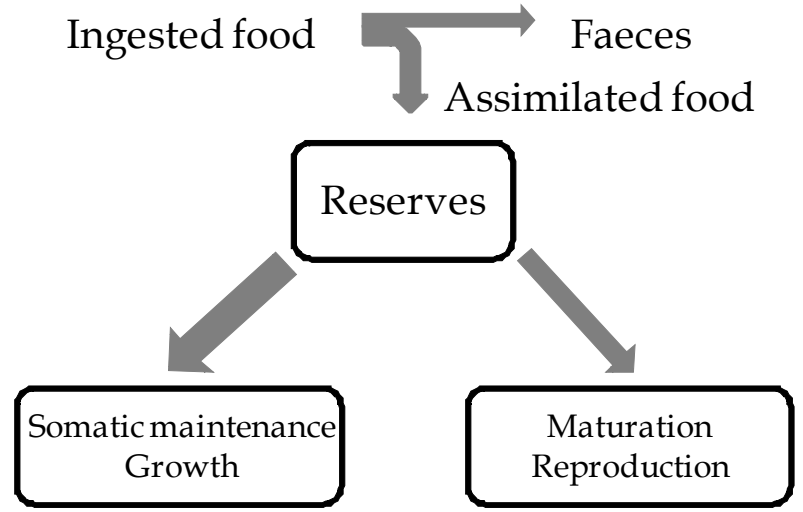

Fig. 9. Schematic representation (modified from van der Meer, 2006) of the Koijman Dynamic Energy Budget model.

and assimilation processes of each reared species must be carefully taken into account in order to maximize the experimental feed efficiency.

\subsection{Fish}

A limiting factor in larvicolture of many fish and crustaceans is the availability and nutritional value of live food. Larvae of many species have been raised using Artemia salina naupli and rotifers. However, their nutritional quality may change according to the source and the time of harvest of cysts. Formulated feed is by far more attractive due to the possibility to adjust its composition and size to the nutritional needs of the species. Most commercial larval diets are microbound diets, where binders are used to stabilize feed pellets and ensure minimum leaching and disintegration (Hashim and Saat, 1992). Carrageenan containing pellets are suitable for the ayu, Plecoglossus altivellis (Teshima et al., 1982), but not for postlarval tongue sole (Cynoglossus semilaevis) (Liu et al., 2008). Both alginate and zein appear to be suitable for farming larvae of sea bass (Dicentrarchus labrax) (Person Le Ruyet et al., 1993) but not barramundi (Lates calcalifer) (Partridge \& Southgate, 1999), although Lee et al. (1996) previously reported that Lates calcifer larvae were able to digest both alginate and gelatine bound diets. Sodiumcarboxymethilcellulose, sodium alginate and gelatin included in feed for postlarval tongue sole (Cynoglossus semilaevis) brought about a growth similar to controls (Liu et al., 2008). Recently, a microbound diet containing soy lecithin, wheat gluten, and alginate has been patented for the culture of larval fish and crustaceans (D'Abramo, 2003).

\subsection{Crustaceans}

Dietary binders have been tested for growth performance in several species, with often conflicting results. Wheat flour, whole cassava meal and dry molasses were effective binders and caused the highest weight gain in crayfish Macrobrachium rosenbergii post-larvae, in comparison to agar (Seixas Filho et al., 1997a), although agar containing pellets had the best texture (Seixas Filho et al., 1997b). Unfortunately, no comparison with a control group fed natural diet was provided in this study. In contrast, Kovalenko et al. (2002) report that 
growth of larvae fed alginate containing feed, was only $90 \%$ of that achieved for larvae fed natural diet (newly hatched nauplii of Artemia). Both lignosol and agar brought about a significant increase in weight in juvenile shrimp Palaemonetes varians and Palaemon elegans (Palma et al., 2008). Alginate, agar and pectin caused good growth performance in both Cherax albidus juveniles and adults with respect to control animals fed natural diet, with pectin giving the best results in both juveniles and adults (Volpe et al., 2008; Coccia et al., 2010).

\subsection{Molluscs}

Alginate and gelatin have been tested on cephalopod growth. The presence of alginate as food binder in Octopus maya negatively affected growth rate and survival even when added at a very low percentage. Indeed, Octopus maya fed alginate-bound crab showed a survival rate of only $15 \%$ with respect to the control group fed with crabs (Rosas et al., 2008). Both Octopus maya and Octopus vulgaris fed diets containing alginate and gelatin as binders grew significantly less than the controls fed natural diets (Rosas et al., 2008; Valverde et al., 2008; Garcia et al., 2011).

Konjac glucomannan and xanthan gum were used together in different configurations (1:1; 1:3) in feed for abalone (Haliotis discus hannai). Although no differences in growth have been recorded between treatments, growth parameters were significantly higher in animals fed a natural diet (O'Mahoney et al., 2011).

\subsection{Sea urchins}

The rapid expansion of the culture of sea urchins has increased the demand for formulated feed, specifically developed taking into account the echinoids needs. It has been widely demonstrated as prepared diets increase both test growth and gonad yield with respect to natural food (Pearce et al., 2004; Otero-Villanueva et al., 2004; Schlosser et al., 2005; Azad et al., 2011) and also feed initially formulated for other species than echinoids proved to successfully support urchins' growth and gonad maturation (Fabbrocini \& D'Adamo, 2010). On the other hand, these diets frequently lead to poor gonad quality in terms of texture, firmness, colour and taste (Pearce et al., 2002b; Schlosser et al., 2005), that means low marketability of the product. For these reasons research focused on the formulation of suitable feed for sea urchin must take into account the effects on both gonad yield and sensory quality of both the components of the experimental diets and the binders used to give consistence to the pellets. Numerous binders have been successfully employed in the formulation of feed for different sea urchin species. In many echinoid species gelatin based pellets lead to a greater urchin growth (Fernandez \& Pergent, 1998; Daggett et al., 2005) and a higher gonad yield (Pearce et al., 2004; Barker et al., 2006; Phillips et al., 2009) with respect to urchin fed on fresh macroalgae; also a pellet based on gelatin strengthened with the enzyme transglutaminase ( $\gamma$-glutamyltransferase) gave better results in terms of gonad index with respect to Laminaria hyperboreus diet in Strongylocentrotus droebachiensis (Mortensen et al., 2004). Similarly, a feed containing a mixed binder gelatin-sodium alginate supported juveniles growth of Strongylocentrotus droebachiensis better than fresh Laminaria (Kennedy et al., 2007). Also agar (Barker et al., 1998), sodium alginate (Akiyama et al., 2001; Pearce et al., 2002b), guar gum and corn starch (Pearce et al., 2002b) based pellets gave better results in terms of gonad indices with respect to a natural diet. Despite the fact that much of 
the research on sea urchin rearing in confined conditions has focused on the formulation of prepared feed, few published studies have examined the effects of the binder nature and concentration on urchins' gonad growth and sensory quality.

Akiyama et al (1997) tested the effectiveness as a binder of $30 \%$ sodium alginate and of $15 \%$ Curdlan $^{\mathrm{TM}}$, a polysaccharide produced by the bacteria Alcoligenes faecalis var. myxogenes and commonly used in human foods. They found that gonad growth in Pseudocentrotus depressus was higher with alginate based feed, with respect to Curdlan ${ }^{\mathrm{TM}}$ based pellet. Pearce et al. (2002b) tested different experimental feed which differed only for the binder type (gelatin, guar gum, sodium alginate, and corn starch) and concentration (3\% and $5 \%)$, in order to evaluate the binder effect on gonad growth of Strongylocentrotus droebachiensis. Even if gonad growth was faster with gelatin and alginate based pellets, at the end of the trial (12 weeks) gonad indices (GI) were similar for the various binders at the higher concentration (5\%), while it was slightly lower with 3\% guar gum and corn starch. Fabbrocini et al. (2011) tested the effectiveness of agar based pellets for gonad growth and gamete production in Paracentrotus lividus. Pellets made of commercial feed Classic ${ }^{\odot}$ (hendrix) and 3\% agar gave the same results of the Classic ${ }^{\odot}$ alone, therefore agar did not hamper gonad growth; in addition, urchins fed on Ulva-agar pellets in a 4 weeks rearing trial progressed in the reproductive cycle as those fed on commercial feed, showing comparable gonad indices levels. Regarding gonad sensory quality, a prepared diet with a high content of gelatin gave good results in Evechinus chloroticus (Phillips et al., 2009). On the contrary, in Strongylocentrotus droebachiensis a gelatin-transglutaminase based diet gave poor results in terms of gonad taste (Mortensen et al., 2004), while the best results in terms of gonad colour were obtained with a starch-based pellet by Pearce et al. (2002b). All these considered, when choosing the binder it is crucial to take into account the urchin species to be reared and the objective to be reached: urchin growth, gonad yield and gamete production, or gonad sensory quality.

In Table 3 the effect of feed binders on growth are reported.

\section{Binder effect on feed digestibility}

Several reports indicate a relationship between binders and nutrient digestibility. Different techniques are used for evaluating feed digestibility (Khan et al., 2003) among which the total collection technique, although time-consuming and stressful for the animal, is the most reliable method. The feed is fed in known quantities to the animal and accurate records of feed intake and fecal output are kept. Thus, it is foreseeable that digestibility experiments in aquatic animals are prone to errors related to the difficulty of measuring the correct amount of feed ingested and the methods employed to collect feces (i.e., settlement, filtration) which result in leaching losses (Irvin \& Tabrett, 2005). It has been shown that the settlement collection method results in an overestimation of protein digestibility by up to $6 \%$ when feces are collected once every $6 \mathrm{~h}$ rather than hourly post-feeding in shrimp (Smith \& Tabrett, 2004). Alternatively, in vitro techniques may be used to provide a quick and low cost method to predict nutrient digestibility. The digestibility of several carbohydrate sources for juveniles of the spiny lobster Jasus edwardsii has been estimated by measuring their rates of hydrolysis in vitro using enzyme homogenates and postprandial haemolymph glucose concentrations following ingestion of semi-purified diets (Simon, 2009). Many different factors influence the efficiency of digestion. The impact of binder type on feed digestibility 


\begin{tabular}{|c|c|c|c|c|}
\hline BINDER & $\begin{array}{l}\text { \% Binder } \\
\text { employed }\end{array}$ & SPECIES & GROWTH & Reference \\
\hline \multicolumn{5}{|c|}{ CARBOHYDRATES } \\
\hline \multirow[t]{5}{*}{ Agar } & 2 & $\begin{array}{l}\text { Palemonetes } \\
\text { varians (juveniles) }\end{array}$ & Positive & \multirow[t]{2}{*}{$\begin{array}{l}\text { Palma et al., } \\
2008\end{array}$} \\
\hline & 2 & $\begin{array}{l}\text { Palemon elegans } \\
\text { (juveniles) }\end{array}$ & Positive & \\
\hline & 2.5 & $\begin{array}{l}\text { Cherax albidus } \\
\text { (adults) }\end{array}$ & Positive & $\begin{array}{l}\text { Volpe et al., } \\
2008\end{array}$ \\
\hline & 2 & $\begin{array}{l}\text { Cherax albidus } \\
\text { (juveniles) }\end{array}$ & Positive & $\begin{array}{l}\text { Coccia et al., } \\
2010\end{array}$ \\
\hline & 3 & $\begin{array}{l}\text { Paracentrotus } \\
\text { lividus (adults) }\end{array}$ & $\begin{array}{l}\text { Same as } \\
\text { control }\end{array}$ & $\begin{array}{l}\text { Fabbrocini et } \\
\text { al., } 2011\end{array}$ \\
\hline \multirow[t]{10}{*}{ Alginate } & 2.5 & $\begin{array}{l}\text { Cherax albidus } \\
\text { (adults) }\end{array}$ & Positive & $\begin{array}{l}\text { Volpe et al., } \\
2008\end{array}$ \\
\hline & 5.38 & $\begin{array}{l}\text { Macrobrachium } \\
\text { rosembergi (larvae) }\end{array}$ & Negative & $\begin{array}{l}\text { Kovalenko et } \\
\text { al., } 2002\end{array}$ \\
\hline & 10 & Octopus vulgaris & Negative & $\begin{array}{l}\text { Garcia et al., } \\
2011\end{array}$ \\
\hline & 1 & Octopus Maya & Negative & $\begin{array}{l}\text { Rosas et al., } \\
2008\end{array}$ \\
\hline & 30 & Octopus vulgaris & Negative & $\begin{array}{l}\text { Valverde et al., } \\
2008\end{array}$ \\
\hline & 2 & $\begin{array}{l}\text { Cynoglossus } \\
\text { semilaevis } \\
\text { (postlarvae) }\end{array}$ & $\begin{array}{l}\text { Same as } \\
\text { control }\end{array}$ & Liu et al., 2008 \\
\hline & 2 & $\begin{array}{l}\text { Cherax albidus } \\
\text { (juveniles }\end{array}$ & Positive & $\begin{array}{l}\text { Coccia et al., } \\
2010\end{array}$ \\
\hline & 30 & $\begin{array}{l}\text { Pseudocentrotus } \\
\text { depressus } \\
\text { (juveniles) }\end{array}$ & $\begin{array}{l}\text { Negative vs } \\
\text { control } \\
\text { Positive vs } \\
\text { curdlan } \AA \\
\end{array}$ & $\begin{array}{l}\text { Akiyama et al., } \\
1997\end{array}$ \\
\hline & 30 & $\begin{array}{l}\text { Pseudocentrotus } \\
\text { depressus } \\
\text { (juveniles) }\end{array}$ & Positive & $\begin{array}{l}\text { Akiyama et al., } \\
2001\end{array}$ \\
\hline & $3 ; 5$ & $\begin{array}{l}\text { Strongylocentrotus } \\
\text { droebachiensis } \\
\text { (adults) }\end{array}$ & Positive & $\begin{array}{l}\text { Pearce et al., } \\
2002 b\end{array}$ \\
\hline $\begin{array}{l}\text { Carboxymethyl } \\
\text { cellulose }\end{array}$ & 2 & $\begin{array}{l}\text { Cynoglossus } \\
\text { semilaevis }\end{array}$ & $\begin{array}{l}\text { Same as } \\
\text { control }\end{array}$ & \multirow[t]{2}{*}{ Liu et al., 2008} \\
\hline Carrageenan & 2 & $\begin{array}{l}\text { Cynoglossus } \\
\text { semilaevis }\end{array}$ & Negative & \\
\hline Chitosan & 1 & $\begin{array}{l}\text { Cherax albidus } \\
\text { (juveniles) }\end{array}$ & Positive & $\begin{array}{l}\text { Coccia et al., } \\
2010\end{array}$ \\
\hline $\begin{array}{l}\text { Konjac } \\
\text { glucomannan- } \\
\text { xanthan gum }\end{array}$ & $0.1 ; 7,5$ & $\begin{array}{l}\text { Haliotis discus } \\
\text { hannai }\end{array}$ & Negative & $\begin{array}{l}\text { O'Mahoney et } \\
\text { al., } 2011\end{array}$ \\
\hline
\end{tabular}




\begin{tabular}{|c|c|c|c|c|}
\hline BINDER & $\begin{array}{l}\text { \% Binder } \\
\text { employed }\end{array}$ & SPECIES & GROWTH & Reference \\
\hline Guar gum & $3 ; 5$ & $\begin{array}{l}\text { Strongylocentrotus } \\
\text { droebachiensis } \\
\text { (adults) }\end{array}$ & Positive & $\begin{array}{l}\text { Pearce et al., } \\
2002 b\end{array}$ \\
\hline \multirow[t]{2}{*}{ Lignosol } & 2 & $\begin{array}{l}\text { Palemonetes } \\
\text { varians (juveniles) }\end{array}$ & Positive & \multirow[t]{2}{*}{$\begin{array}{l}\text { Palma et al., } \\
2008\end{array}$} \\
\hline & 2 & $\begin{array}{l}\text { Palemon elegans } \\
\text { (juveniles) }\end{array}$ & Positive & \\
\hline Corn starch & $3 ; 5$ & $\begin{array}{l}\text { Strongylocentrotus } \\
\text { droebachiensis } \\
\text { (adults) }\end{array}$ & Positive & $\begin{array}{l}\text { Pearce et al., } \\
2002 b\end{array}$ \\
\hline \multirow[t]{2}{*}{ Pectin } & 2.5 & $\begin{array}{l}\text { Cherax albidus } \\
\text { (adults) }\end{array}$ & Positive & $\begin{array}{l}\text { Volpe et al., } \\
2008\end{array}$ \\
\hline & 1 & $\begin{array}{l}\text { Cherax albidus } \\
\text { (juveniles) }\end{array}$ & Positive & $\begin{array}{l}\text { Coccia et al., } \\
2010\end{array}$ \\
\hline \multicolumn{5}{|l|}{ PROTEINS } \\
\hline \multirow[t]{7}{*}{ gelatin } & 10 & Octopus vulgaris & Negative & $\begin{array}{l}\text { Garcia et al., } \\
2011\end{array}$ \\
\hline & 2 & Octopus Maya & $\begin{array}{l}\text { Same as } \\
\text { control }\end{array}$ & $\begin{array}{l}\text { Rosas et al., } \\
2008\end{array}$ \\
\hline & 10 & Octopus vulgaris & Negative & $\begin{array}{l}\text { Valverde et al., } \\
2008\end{array}$ \\
\hline & 2 & $\begin{array}{l}\text { Cynoglossus } \\
\text { semilaevis } \\
\text { (postlarvae) }\end{array}$ & $\begin{array}{l}\text { Same as } \\
\text { control }\end{array}$ & Liu et al., 2008 \\
\hline & $3 ; 5$ & $\begin{array}{l}\text { Strongylocentrotus } \\
\text { droebachiensis } \\
\text { (adults) }\end{array}$ & Positive & $\begin{array}{l}\text { Pearce et al., } \\
2002 b\end{array}$ \\
\hline & 5 & $\begin{array}{l}\text { Strongylocentrotus } \\
\text { droebachiensis } \\
\text { (juveniles) }\end{array}$ & Positive & $\begin{array}{l}\text { Pearce et al., } \\
2002 b\end{array}$ \\
\hline & 5 & $\begin{array}{l}\text { Strongylocentrotus } \\
\text { droebachiensis } \\
\text { (juveniles) }\end{array}$ & Positive & $\begin{array}{l}\text { Daggett et al., } \\
2005\end{array}$ \\
\hline \multicolumn{5}{|l|}{ MIXED BINDERS } \\
\hline $\begin{array}{l}\text { Gelatin+ } \\
\text { transglutaminase }\end{array}$ & $\begin{array}{l}? \\
0.13 \%\end{array}$ & $\begin{array}{l}\text { Strongylocentrotus } \\
\text { droebachiensis } \\
\text { (juveniles) }\end{array}$ & Positive & $\begin{array}{l}\text { Mortensen et } \\
\text { al., } 2004\end{array}$ \\
\hline $\begin{array}{l}\text { Gelatin+ } \\
\text { alginate }\end{array}$ & $\begin{array}{l}5 \\
2\end{array}$ & $\begin{array}{l}\text { Strongylocentrotus } \\
\text { droebachiensis } \\
\text { (juveniles) }\end{array}$ & Positive & $\begin{array}{l}\text { Kennedy et al., } \\
2007\end{array}$ \\
\hline
\end{tabular}

Table 3. Effect of feed binders on growth

is another of a series of factors that must be taken into consideration when designing a formulated feed type that is intended to be successful. High concentrations of binder may in fact cause a reduction in diet digestibility. Measuring the apparent digestibility of binders is 
necessary in order to better understand their bioavailability when incorporated in formulated diets and their potential influence on the digestibility of other major macroingredients such as protein. Unfortunately, the effect of binders on diet digestibility has been largely overlooked. Simon (2009) found that gelatin, but not agar or alginate $(7-8 \%$ inclusion level), positively affected digestibility in the juveniles of the lobster Jasus edwardsii. Similarly, Octopus maya fed alginate containing pellets lost weight and died, suggesting that this binder negatively affects nutrient absorption, while gelatin promoted absorption of nutrients (Rosas et al., 2008). It seems that binders have detrimental effects on nutrient digestibility in fish, as they accelerate gastrointestinal transit time (Storebakken, 1985). The inclusion of guar gum to tilapia feed has nutrient digestibility coefficients lower than diets containing CMC, corn starch and wheat gluten (Fagbenro \& Jauncey, 1995). This is in line with previous results showing that fish feed containing highly effective binders had negative effects on macronutrient digestibility probably due to physical effects, such as changes in viscoelastic properties (Storebakken \& Austreng, 1987; Storebakken et al., 1998). Recently, the effect of two natural binders (fava and kidney beans) on protein and lipid digestibility in the Atlantic salmon Salmo salar showed no significant differences between the dietary treatments (Pratoomyot et al., 2011) and the addition of guar gum to the diet of rainbow trout positively affected digestibility when employed with plant meal (Brinker \& Reiter, 2011). The pattern of food residence in the gut was found to vary little with diet or urchin size (38-42h) in Psammechinus miliaris (Otero-Villanueva et al., 2004). Lawrence et al. (1989) found that in Paracentrotus lividus gut passage-time and apparent dry matter digestibility were similar with agar-based feed containing either soybean or fish meals. Similar results were reported by Klinger et al. (1994) for Litechinus variegatus. No differences in absorption efficiency were recorded for Evechinus chloroticus fed on extruded or agarbased pellets (Barker et al., 1998). In Pseudocentrotus depressus feed efficiency was higher for alginate- based pellets than for kelp (Akiyama et al., 2001), while regarding the effect of different binders, alginate-based pellets showed a lower feed efficiency than Curdlan ${ }^{\mathrm{TM}}$ based ones (Akiyama et al., 1997).

\section{Binder effect on digestive enzymes}

It is commonly agreed that species exhibit a particular suite of digestive enzymes that reflect their different life history (Figueiredo \& Anderson, 2009). Consequently, from the digestive enzyme profile it is possible to predict the ability of the species to use different nutrients. Since the digestive enzyme activity is high for those substrates that are more common in the diet (Moss et al., 2001) there is a common belief that the activity of digestive enzymes can be boosted by providing certain nutrients into the diet for an adequate amount of time.

It is well known that crustaceans adapt their digestive enzymatic profile and activity to the diet composition (Muhlia-Almazan et al., 2003; Johnston \& Freeman, 2005; Pavasovic et al., 2007a), as a consequence of an enzymatic battery capable of hydrolyzing the wide variety of substrates that they encounter in their natural diet (Linton et al., 2009). Modifications in digestive enzyme activity in different penaeid shrimp larvae have been related to the quantity or quality of some component of the diet (Le-Vay et al., 1993; Rodriguez et al., 1994; Le Moullac et al., 1997; Lemos \& Rodriguez, 1998; Brito et al., 2000). Protein composition of the diet increased protease activity in Marsopenaeus japonicas juveniles and Litopenaeus vannamei larvae (Van Wormhoudt et al., 1986; Le Moullac \& Van Wormhoudt, 1994; Le Moullac et al., 1997). Some authors suggest that the increase in amylase activity found in 
Penaeus monodon (Fang \& Lee, 1992), and Litopenaeus vannamei (Brito et al., 2000), may be related to the low level of carbohydrate in the diet (Le Vay et al., 1993; Rodriguez et al., 1994; Kumlu \& Jones, 1995; Lemos \& Rodriguez, 1998). Protease, amylase and cellulase activities have been found to be positively correlated with dietary protein levels (Pavasovic et al., 2007b), and negatively correlated with high cellulose levels (Pavasovic et al., 2006). In contrast, in the white shrimp Penaeus vannamei dietary protein level did not influence total protease activity, although modulation of trypsin- and chymotrypsin-like activities has been documented (Muhlia-Almazan et al., 2003). Moreover, no significant difference was observed in protease activity of Litopenaeus vannamei (Rivas-Vega et al., 2006) and Scylla serrata subjected to different dietary treatments (Pavasovic et al., 2004). In Cherax quadricarinatus the digestive enzyme secretion is modified by the diet composition, such as the presence of animal- or plant-derived ingredients (Lopez-Lopez et al., 2005; Pavasovic et al., 2007a). In the mollusk Babylonia areolate a positive correlation between dietary lipid level and lipase activity has been reported (Zhou et al., 2007). Among teleosts, proteolytic activity has been found unresponsive to the protein content of the diet in Pseudoplatystoma corruscans (Lundstedt et al., 2004) and in early weaned sea bass (Dicentrarchus labrax) larvae (Cahu \& Zambonino-Infante, 1994), but not in Colossoma macropomum, where digestive protease increased along with dietary protein content (De Almeida et al., 2006). On the other hand, alkaline protease activity was higher in Dentex dentex fed a diet with less protein and more carbohydrates (Perez-Jimenez et al., 2009). Amylase activity was higher in Pseudoplatystoma corruscans fed diets containing $13-25 \%$ of starch and similarly, it could be adjusted through the starch level of the diet in Colossoma macropomum (De Almeida et al., 2006) and Dentex dentex (Perez-Jimenez et al., 2009). A positive correlation has been observed between lipase and dietary lipid levels in Colossoma macropomum (De Almeida et al., 2006) and Lateolabrax japonicus (Luo et al., 2010). In any case the emerging picture in teleosts is one of wide complexity and variability due to the different of habitats and life histories of such vertebrates.

Virtually no studies have been carried out with the main purpose of investigating the effect of feed binders on digestive enzyme activity. The effect of different binders on digestive enzymes profile has been studied by us in Cherax albidus (Volpe et al., submitted). In an attempt to understand if the presence of binders influenced the digestive enzymatic profile we undertook a screening of carbohydratases, lipases and proteases along the digestive tract of juvenile Cherax albidus under both natural diet (Coccia et al., 2011) and different experimental diets based on pellets containing different binders but the same proximate composition. We found that digestive enzyme activities did not statistically show significant differences in the digestive tract except for amylase that was significantly higher in the intestine compared to the gastric juice and hepatopancreas of animals fed pectin containing pellets for 12 weeks.

\section{Conclusion}

Good water stable pellets are a major concern for the aquaculture industry. Binder agents have been widely employed to improve the stability of aquatic animal feed. Binders are believed to prevent or at least reduce major nutrient loss and feed softness which is inevitable when pellets stay in water for long periods of time. Preventing or reducing such an inconvenient would have beneficial consequences on the aquaculture industry. Binder prices may significantly affect the cost of the diet, therefore the utilization of natural 
substances, biodegradable and renewable may be advantageous from an environmental and economical point of view. Although there is not such a thing as the best binding agent, the research in this field is actively ongoing, since different species and even the same species during different phases of the life cycle have different feeding behaviours and nutritional needs. However, despite progress in recent years, knowledge of microbound diets and their impact on digestive physiology and growth performances of reared aquatic species is still not sufficient in light of the industry's needs and thus further research is required.

\section{References}

Ahmed, J.; Ramaswamy, H.S. ; Ngadi, M.O.(2005). Rheological characteristics of Arabic gum in combination with guar and xanthan gum using response surface methodology: Effect of temperature and concentration. International Journal of Food Properties, Vol. 8, No. 2, (April 2005), pp. 179-192, ISSN 1094-2912

Akiyama, T.; Unuma, T.; Yamamoto, T.; Furuita, H. \& Konishi, K. (1997). An evaluation of amino acid sources and binders in semipurified diet for red sea urchin Pseudocentrotus depressus. Fisheries Science, Vol. 63, No. 6, pp. 881-886, (December 1997), ISSN 1444-2906

Akiyama, T.; Unuma T. \& Yamamoto, T. (2001). Optimum protein level in a purified diet for young red sea urchin Pseudocentrotus depressus. Fisheries Science, Vol. 67, No. 2, (April 2001), pp. 361-363, ISSN 1444-2906

Aspinall, G.O. (1982) Chemical characterization and structure determination of polysaccharides. In: The Polysaccharides, Aspinall G.O. (ed.), Vol. 1, pp. 35-131, Academic Press, Inc., New York

Arisz, P.W.; Kauw, H.J.J. \& Boon, J.J. (1995) Substituent distribution along cellulose backbone in O-methylcelluloses using GC and FAB-MS for monomer and oligomer analysis. Carbohydrate Research, Vol. 271, No. 1, (July 1995), pp. 1-14, ISSN 0008-6215

Atkins, E. D. T. (Ed.). (1985). Polysaccharides: Topics in structure and morphology. Wiley-VCH Verlag GmbH, ISBN 9783527264100, Germany

Azad, A.K.; Pearce, C.M. \& McKinley R.S. (2011). Effects of diet and temperature on ingestion, absorption, assimilation, gonad yield, and gonad quality of the purple sea urchin (Strongylocentrotus purpuratus). Aquaculture, Vol. 317, No. 1-4, (July 2011), ISSN 0044-8486

Barker, M.F.; Keogh, J.A.; Lawrence, J.M. \& Lawrence, A.L. (1998). Feeding rate, absorption efficiencies, growth, and enhancement of gonad production in the New Zealand sea urchin Evechinus chloroticus Valenciennes (Echinoidea: Echinometridae) fed prepared and natural diets. Journal of Shellfish Research, Vol. 17, No. 5, (December 1998), pp. 1583-1590, ISSN 0730-8000

Barker, M.F.; Bremer, P.; Silcock, P.; Delahunty, C. \& Sewell, M. (2006). Enhancement of yield and quality of Evechinus chloroticus roe through controlled diet. Journal of Shellfish Research, Vol. 25, No. 2, (August 2006), p. 711, ISSN 0730-8000

Bautista M.N.; Millamena, O.M. \& Kanazawa, A. (1989). Use of kappa-carrageenan microbound diet (C-MBD) as feed for Penaeus monodon larvae. Marine Biology, Vol. 103, pp. 169-173, ISSN 0025-3162

Brinker, A. (2007). Guar gum in rainbow trout (Oncorhynchus mykiss) feed: the influence of quality and dose on stabilization of faecal solids. Aquaculture, Vol. 267, No.1-4, (July 2007), pp. 315-327, ISSN 0044-8486 
Brinker, A. \& Reiter, R. (2011). Fish meal replacement by plant protein substitution and guar gum addition in trout feed, Part I: Effects on feed utilization and fish quality. Aquaculture, Vol. 310, No. 3-4, (January 2011), pp.350-360, ISSN 0044-8486

Brito R.; Chimal, M.E.; Gaxiola, G. \& Rosas, C. (2000). Growth, metabolic rate, and digestive enzyme activity in the white shrimp Litopenaeus setiferus early postlarvae fed different diets. Journal of Experimental Marine Biology and Ecology, Vol. 255, No. 1, (December 2000), pp. 21-36. ISSN 0022-0981

Cahu, C.L. \& Zambonino-Infante, J.L. (1994). Early weaning of sea bass (Dicentrarchus labrax) larvae with a compound diet: effect on digestive enzymes. Comparative Biochemistry and Physiology part A, Vol. 109, No. 2 (October 1994), pp. 213-222, ISSN 1095-6433

Caltagirone, A.; Francour, P. \& Fernandez C. (1992). Formulation of an artificial diet for the rearing of the urchin Paracentrotus lividus: I. Comparison of different binding agents. In: Echinoderm Research L. Scalera-Liaci, C. Canicattì (Eds), pp. 115-119, ISBN 90-5410-049-4, Balkema, Rotterdam

Castillo-García, E.; López-Carballo, G. \& López-Castellano, A. (2005). Guar gum characteristics and applications. Ciencia y Tecnologia Pharmaceutica, Vol. 15, No. 1, (March 2005), pp. 3-10, ISSN 1575-3409

Cerver, M.F.; Heinämäki, J.; Räsänen, M.; Maunu, S.L.; Karjalainen, M.; Acosta, O.M., Colart, A. I. \& Yliruusi, J. (2004). Solid-state characterization of chitosan derived from lobster chitin. Carbohydrate Polymers, Vol. 58, No. 4-7, (December 2004), pp. 401-408, ISSN 0144-8617

Chevanan, N.; Muthukumarappan, K. \& Rosentrater, K. A. (2009). Extrusion Studies of Aquaculture Feed using Distillers Dried Grains with Solubles and Whey. Food and Bioprocess Technology, Vol. 2, No. 2, (March 2009), pp. 177-185, ISSN 1935-5130

Clark, A. H. \& Ross-Murphy, S. B. (1987). Structural and mechanical properties of biopolymers gels. In: Advances in Polymer Science, Vol. 83 (October 1987), pp. 57192, ISSN 0065-3195

Coccia, E.; Santagata, G.; Malinconico, M.; Volpe, M.G.; Di Stasio, M. \& Paolucci, M. (2010) Cherax albidus juveniles fed polysaccharide-based pellets: rheological behavior and effect on growth. Freshwater crayfish, Vol. 17, pp.13-18, ISBN 978-951-27-1322-6

Coccia, E.; Varricchio, E. \& Paolucci, M. (2011). Digestive enzymes in the crayfish Cherax albidus: polymorphism and partial characterization. International Journal of Zoology, Vol. 2011, (March 2011), pp.1-9, ISSN 1687-8477

Coviello, T.; Alhaique, F.; Dorigo, A.; Matricardi, P. \& Grassi, M. (2007). Two galactomannans and scleroglucan as matrices for drug delivery: preparation and release studies. European Journal of Pharmaceutics and Biopharmaceutics, Vol. 66, No. 2, (May 2007), pp. 200-209, ISSN 0939-6411

Cuzon, G.; Guillaume, J. \& Cahu, C. (1994). Composition, preparation and utilization of feeds for Crustacea. Aquaculture, Vol. 124, No.1-4, (June 1994), pp. 253-267, ISSN 0044-8486

D'Abramo, L.R. (2003). Microparticulate microbound diet for the culture of larval fish and crustaceans. US 6645536 (2003)

Daggett, T.L.; Pearce, C.M.; Tingley, M.; Robinson, S.M.C. \& Chopin, T. (2005). Effect of prepared and macroalgal diets and seed stock source on somatic growth of juvenile green sea urchins (Strongylocentrotus droebachiensis). Aquaculture, Vol. 244, No. 1-4, (February 2005), pp. 263-281, ISSN 0044-8486 
De Almeida, L.C.; Lundstedt, L.M. \& Moraes, G. (2006). Digestive enzyme responses of tambaqui (Colossoma macropomum) fed on different levels of protein and lipid. Aquaculture Nutrition, Vol. 12, No. 6, (December 2006), pp. 443-450, ISSN 1353-5773

De Muylder, E.; Hage, H. \& van der Velden, G. (2008). Binders: Gelatin as alternative for urea formaldehyde and wheat gluten in the production of water stable shrimp feeds. Aquafeed International magazine, Volume 11, No. 2, (April 2008), ISSN 14640058

De Silva, S.S. \& T.A. Anderson. (1995). Fish Nutrition in Aquaculture. Chapman \& Hall, ISBN 0412 55030X, London

Dominy, W.G. \& Lim, C. (1991). Performance of binder in pelleted shrimp diets. Proceedings of the aquaculture feed processing and nutrition workshop, pp. 149-157, Thailand and Indonesia, September 1991

Drochner, H.; Kerler, A. \& Zazharias, B. (2004). Pectin in pig nutrition, a comparative review. Journal of Animal Physiology and Animal Nutrition, Vol. 88, No. 11-12, (April 2004), pp. 367-380, ISSN 0931-2439

Durazo-Beltran, E. \& Viana, M.T. (2001). Effect of the concentration of agar, alginate and carrageenan on the stability, toughness and nutrient leaching in artificial diets for abalone. Ciencias marinas, vol. 27, No. 1, pp. 1-19, ISSN 0185-3880

El-hefian, E.A.; Nasef, M.M. \& Yahaya, A.H. (2011). Chitosan physical forms: A short review. Australian Journal of Basic and Applied Sciences Vol.5, No. 5, (May 2011), pp. 670-677, ISSN 19918178677

Fabbrocini, A. \& D'Adamo, R. (2010). Gamete maturation and gonad growth in fed and starved sea urchin Paracentrotus lividus (Lamarck, 1816). Journal of Shellfish Research, Vol. 29, No. 4, (December 2010), pp. 1051-1059, ISSN 0730-8000

Fabbrocini, A.; Volpe, M.G.; Di Stasio, M.; D’Adamo, R.; Maurizio, D.; Coccia, E. \& Paolucci, M. (2011). Agar-based pellet as feed for sea urchins (Paracentrotus lividus): rheological behaviour, digestive enzymes and gonad growth. Aquaculture Research, (in press, DOI: 10.1111/j.1365-2109.2011.02831.x), ISSN 1365-2109

Fagbenro, O. \& Jauncey, K. (1995). Water stability, nutrient leaching and nutritional properties of moist fermented fish silage diets. Aquaculture Engineering, Vol. 14, No. 4, pp. 143-153, ISSN 0144-8609

Falayi, B.A.; Sadiku, S.O.; Eyo, A.A. \& Okaeme, A.N. (2006). Water stability and floatation of fish diets bound with different agents and Saccharomyces cerivisiae. Nigerian Journal of Fisheries, Vol 2, No. 3, pp. 181-196, ISSN 1597-443.

Fang, L.S. \& Lee, B.N. (1992). Ontogenic change of digestive enzymes in Penaeus monodon. Comparative Biochemistry and Physiology Part B: Comparative Biochemistry, Vol. 103, No. 4, (December 1992), pp. 1033-1037, ISSN 1096-4959

Farris, S.; Schaich, K. M.; Liu, L.; Piergiovanni, L. \& Yam, K. L. (2009). Development of polyion-complex hydrogels as an alternative approach for the production of biobased polymers for food packaging applications: a review. Trends in Food Science and Technology, Vol. 20, No. 2, (February 2009), pp. 316-332, ISSN 0924-2244

Fernandez, C. \& Pergent, G. (1998). Effect of different formulated diets and rearing conditions on growth parameters in the sea urchin Paracentrotus lividus. Journal of Shellfish Research, Vol. 17, No. 5, (December 1998), pp. 1571-1581, ISSN 0730-8000 
Figueiredo, M.S.R.B., \& Anderson, A.J. (2009). Digestive enzyme spectra in crustacean decapods (Paleomonidae, Portunidae and Penaeidae) feeding in the natural habitat. Aquaculture Research, Vol. 40, No. 3, (February 2009), pp. 282-291, ISSN 1365-2109

Forbes, J.M. (2001). Consequences of feeding for future feeding. Comparative Biochemistry and Physiology Part A: Molecular \& Integrative Physiology, Vol. 128, No. 3, (March 2001), pp. 463-70, ISSN 1095-6433

Garcia, S.; Domingues, P.; Navarro, J.C.; Hachero, I.; Garrido, D. \& Rosas, C. (2011). Growth, partial energy balance, mantle and digestive gland lipid composition of Octopus vulgaris (Cuvier, 1797) fed with two artificial diets. Aquaculture Nutrition, Vol. 17, No. 2 (April 2011), pp. e174-e 187, ISSN 1353-5773

Genodepa, J.; Zeng, C. \& Southgate, P. C. (2004). Preliminary assessment of a microbound diet as an Artemia replacement for mud crab, Scylla serrata, megalopa. Aquaculture, Vol. 236, No. 1-4 (June 2004), pp. 497-509, ISSN 0044-8486

Genodepa, J.; Zeng, C. \& Southgate, P. C. (2007). Influence of binder type on leaching rate and ingestion of microbound diets by mud crab, Scylla serrata (Forsskal), larvae. Aquaculture Research, Vol. 38, No. 14, (October 2007), pp. 1486-1494, ISSN 1365-2109

Goldstein, A.M.; Alter, E.N. \& Seaman, J.K. (1973). Guar gum, In: Industrial Gums, Polysaccharides and their Derivatives Whistler R.L. Ed., pp. 303-321, Academic Press, New York

Grant, N. H.; Clark, D. E. \& Rosanoff, E. I. (1973). Biochemical and Biophysical Research Communications, Vol. 51, pp. 100-106, ISSN 0006-291X

Grasdalen, H.; Larsen, B. \& Snidsrod, O. (1981). 13C-N.M.R. studies of monomeric composition and sequence in alginate Carbohydrate Research, Vol. 89, No. 2, (January 1981), pp. 179-191, ISSN 0008-6215

Hashim, R. \& Saat, M.A.M. (1992). The utilization of seaweed meals as binding agents in pelleted feeds for snakehead (Channa striatus) fry and their effects on growth. Aquaculture, Vol. 108, No. 3-4, (December 1992), pp. 299-308, ISSN 0044-8486

Holdich, D.M. (2002). Biology of freshwater crayfish. Blackwell Science, ISBN 978-0-632-054312, United Kingdom.

Irvin, S.J. \& Tabrett, S.J. (2005). A novel method of collecting fecal samples from spiny lobsters. Aquaculture, Vol. 243, No. 1-4, (January 2005), pp. 269-272, ISSN 0044-8486

Johnson, E.L. \& Peniston, Q.P. (1982). Utilization of Shellfish Waste for Chitin, Chitosan Production, In: Chemistry and Bio-chemistry of Marine Food Products, Martin, R.E.; Flick, G.J.; Hebard C.E. \& Ward D.R. eds, pp. 415-428, AVI Publishing Co, ISBN 0870554085, 9780870554087, Westport, CT, USA

Johnston, D.J. \& Freeman, J., (2005). Dietary preference and digestive enzyme activities as indicators of trophic resource utilization by six species of crab. The Biological Bulletin, Vol. 208, No. 1, (February 2005), pp. 36-46, ISSN 0006-3185

Johnston, M. D. \& Johnston, D.L. (2007). Stability of Formulated Diets and Feeding Response of Stage I Western Spiny Lobster, Panulirus cygnus, Phyllosomata. Journal of the World Aquaculture Society, Vol. 38, No.2, (June 2007), pp. 262-271, ISSN 1749-7345

Kalia, A.N. (2005). Textbook of Industrial Pharmacognosy. New Delhi CBS Publishers and Distributors, ISBN 8123912099, India

Kalian, N. \& Morey, R.V. (2009) Factors affecting strength and durability of densified biomass products. Biomass and Bioenergy, Vol. 33, No. 3, (March 2009), pp. 337-359, ISSN 0961-9534 
Kennedy, J.F. \& White, C.A. (1983). Bioactive Carbohydrates, In: Chemistry, Biochemistry and Biology, Kennedy, J.F. \& White, C.A. Eds., pp. 163, Ellis Horwood Publishers, Chichester, United Kingdom

Kennedy, E.J.; Robinson, S.M.C.; Parsons, G.J. \&. Castell, J.D. (2007). Effects of dietary minerals and pigment on somatic growth of juvenile green sea urchins, Strongylocentrotus droebachiensis. Journal of the World Aquaculture Society, Vol. 38, No. 1, (March 2007), pp. 36-48, ISSN 1749-7345

Khan, M.A.; Nisa, M.U. \& Sarwar, M., (2003). Techniques Measuring Digestibility for the Nutritional Evaluation of Feeds. A Review in International Journal of Agriculture and Biology, Vol. 5, No. 1, pp. 91-94, ISSN 1560-8530.

Klinger, T.S.; Lawrence, J.M. \& Lawrence A.L. (1994). Digestive characteristics of the seaurchin Lytechinus variegatus (Lamarck) (Echinodermata: Echinoidea) fed prepared feeds. Journal of the World Aquaculture Society, Vol. 25, No. 4, (December 1994), pp. 489-496, ISSN 1749-7345

Knauer, J.; Britz, P.J. \& Hecht, T. (1993). The effect of seven binding agents on 24-hour water stability of an artificial weaning diet for the South African abalone, Haliotis midae (Haliotidae, Gastropoda). Aquaculture, Vol. 115, No. 3-4, (September 1993), pp. 327-334, ISSN 0044-8486

Koojiman, S.A.L. (2001) Quantitative aspects of metabolic organization: A discussion of concepts. Philosophical Transactions of the Royal Society B: Biological Sciences, Vol. 356, No. 1407, (March 2001), pp. 331-349, ISSN 0962-8436

Kovalenko, E. E.; D’Abramo, L. R.; Ohs, C. L. \& Buddington, R. K. (2002). A successful microbound diet for the larval culture of freshwater prawn Macrobrachium rosenbergii. Aquaculture, Vol. 210, No. 1-4 (July 2002), pp. 385-395. ISSN 0044-8486

Kumlu, M. \& Jones, D.A. (1995). The effect of live and artificial diets on growth, survival, and trypsin activity in larvae of Penaeus indicus. Journal of World Aquaculture Society, Vol.26, No. 4, (December 1995), pp 406-415, ISSN 0893-8849

Lawrence, J.M.; Regis, M.B.; Delmas, P.; Gras, G. \& Klinger T.S. (1989). The effect of quantity and quality of food on feeding and digestion in Paracentrotus lividus (Lamarck) (Echinodermata: Echinoidea). Marine Behaviour and Physiology, Vol. 15, No. 2, (August 1989), pp. 137-144, ISSN 0091-181X

Lee, P.S.; Southgate, P.C. \& Fielder, D.S. (1996). Assessment of two microbound artificial diets for weaning Asian sea bass (Lates calcarifer, Bloch). Asian Fisheries Science, Vol. 9, No.1, pp. 115-120

Lemos, D. \& Rodriguez, A. (1998). Nutritional effects on body composition, energy content and trypsin activity of Penaeus japonicus during early postlarval development. Aquaculture, Vol. 160, No. 1-5 (January 1998), pp. 103-116, ISSN 0044-8486

Le Moullac, G.; Klein, G.B.; Sellos, D. \& Van Wormhoudt, A. (1997). Adaptation of trypsin, chymotrypsin anda-amylase to casein level and protein source in Penaeus vannamei (Crustacea, Decapoda). Journal of Experimental Marine Biology and Ecology, Vol. 208, No. 1-2 ,(January 1997), pp. 107-125, ISSN 0022-0981

Le Moullac, G. \& Van Wormhoudt, A. (1994). Adaptation of digestive enzymes to dietary protein,carbohydrate and fibre levels and influence of protein and carbohydrate quality in Penaeus vannamei larvae(Crustacea, Decapoda), Aquatic Living Resources, Vol. 7, No. 3 (July 1994), pp. 203-210, ISSN 0990-7440 
Le-Vay, L.; Rodriguez, A.; Kamarudin, M.S. \& Jones, D.A. (1993). Influence of live and artificial diets on tissue composition and trypsin activity in Penaeus japonicus larvae. Aquaculture, Vol. 118, No. 3-4 (December 1993), pp. 287-297, ISSN 0044-8486

Lim C. \& Cuzon, G. (1994). Water stability of shrimp pellet: a review. Asian Fisheries Science, Vol 7, No. 2-3, (October 1994), pp. 115-126, ISSN 0116-6514

Linton, S.M.; Allardyce, B.J.; Hagen, W.; Wencke, P. \& Saborowski, R. (2009). Food utilization and digestive ability of aquatic and semi-terrestrial crayfishes, Cherax destructor and Engaeus sericatus (Astacidae, Parastacidae). Jounal of Comparative Physiology, part B, Vol. 179, No. 4, (April 2009), pp. 493-507, ISBN 0174-1578

Liu, F.; Ai, Q.; Mai, K.; Tan, B.; Ma, H.; Xu, W.; Zhang, W. \& LiuFu, Z. (2008). Effects of Dietary Binders on Survival and Growth Performance of Postlarval Tongue Sole, Cynoglossus semilaevis (Günther). Journal of the World Aquaculture Society, Vol. 39, No. 4, (August 2008), pp. 441-571, ISSN 1749-7345

Lopez-Lopez, S.; Nolasco, H.; Villarreal-Colmenares, H. \& Civera-Cerecedo, R. (2005). Digestive enzyme response to supplemental ingredients in practical diets for juvenile freshwater crayfish Cherax quadricarinatus. Aquaculture nutrition, Vol. 11, No. 2, (April 2005), pp. 79-85, ISSN 1353-5773

Lundstedt, L.M.; Melo, J.F. \& Moraes, G. (2004). Digestive enzymes and metabolic profile of Pseudoplatystoma corruscans (Teleostei: Siluriformes) in response to diet composition. Comparative Biochemistry and Physiology, Part B Biochemistry and Molecular Biology, Vol. 137, No. 3 (March 2004), pp. 331-339, ISSN 1096-4959

Luo, G.; Xu, J.; Teng, Y.; Ding, C. \& Yan, B. (2010). Effects of dietary lipid levels on the growth, digestive enzyme, feed utilization and fatty acid composition of Japanese sea bass (Lateolabrax japonicus L.) reared in freshwater. Aquaculture research, Vol. 41, No. 2 (January 2010), pp. 210-219, ISSN 1365-2109

Mortensen, A.; Siikavuopio, S.I. \& Raa, J. (2004). Use of transglutaminase to produce a stabile sea urchin feed. In: Sea Urchins-Fisheries and Ecology Lawrence, J.D. Ed., pp. 203-213. DEStech Publications Inc., ISBN 13 978-1-932078-32-9, ,Landcaster, PA, USA.

Moss, S.M.; Divakaran, S. \& Kim, B.K. (2001). Stimulating effects of the pond water on digestive enzyme activity in the Pacific white shrimp, Litopenaeus vannamei (Bonne). Aquaculture Research, Vol. 32, No. 2, (February 2001), pp. 125-131, ISSN 1365-2109

Muhlia-Almazan, A.; Garcìa-Carreño, F.L.; Sanchez-Paz, J.A.; Yepiz-Plascencia, G. \& Peregrino-Uriarte, A.B. (2003). Effects of dietary protein on the activity and mRNA level of trypsin in the midgut gland of the white shrimp Penaeus vannamei. Comparative Biochemistry and Physiology, part B, Vol. 135, No. 2, (June 2003), pp. 373383, ISSN 1096-4959

Murano, E.; Toffanin, R.; Zanetti, F.; . Knutsen, S.H.; Paoletti, S. \& Rizzo,R. (1992). Chemical and macromolecular characterisation of agar polymers from Gracilariadura (C. Agardh) J. Agardh (Gracilariaceae, Rhodophyta). Carbohydrate Polymers, Vol. 18, No. 3, (October 1992), pp. 171-178, ISSN 0144-8617

No, H.K. \& Meyers, S.P. (1995). Preparation and Characterization of Chitin and Chitosan-A Review. Journal of Aquatic Food Product Technology, Vol. 4, No. 2, (June 1995), pp. 2752, ISSN 1049-8850 
Obaldo, L. G.; Divakaran, S. \& Tacon, A. G. (2002). Method for determining the physical stability of shrimp feeds in water. Aquaculture Research, Vol. 33, No. 5, (April 2002), pp. 369-377, ISSN 1365-2109

O' Mahoney, M.; Mouzakitis, G.; Doyle, J. \& Burnell, G. (2011). A novel konjac glucomannan-xanthan gum binder for aquaculture feeds: the effect of binder configuration on formulated feed stability, feed palatability and growth performance of the Japanese abalone, Haliotis discus hannai. Aquaculture Nutrition, Vol. 17, No. 4, (August 2011), pp. 395-407, ISSN 1353-5773

Orire, A.M.; Sadiku, S.O.E. \& Tiamiyu, L.O. (2010). Evaluation of Yam Starch (Discorea rotundata) as Aquatic Feed Binder. Pakistan Journal of Nutrition, Vol. 9, No. 7, (July 2010), pp. 668-671, ISSN 1680-5194

Otero-Villanueva, M.; Kelly, M.S. \& Burnell, G. (2004). How diet influences energy partitioning in the regular echinoid Psammechinus miliaris; constructing an energy budget. Journal of Experimental Marine Biology and Ecology, Vol. 304, No. 2, (June 2004), pp. 159-181, ISSN 0022-0981

Palma, J.; Bureau, P. \& Andrade, J. P. (2008). Effects of binder type and binder addition on the growth of juvenile Palaemonetes varians and Palaemon elegans (Crustacea: Palaemonidae). Aquaculture International, Vol. 16, No.5, (October 2008), pp. 427-436, ISSN 0967-6120

Paolucci, M. Ed. (2010). Leptin in non mammalian vertebrates. Transworld Research Network. ISBN 978-81-7895-436-3, Trivandrum-695 023, Kerala, India.

Partridge, G.J. \& Southgate, P.C. (1999). The effect of binder composition on ingestion and assimilation of microbound diets (MBD) by barramundi Lates calcarifer Bloch larvae. Aquaculture Research, Vol. 30, No. 11-12, (November 1999), pp. 879-886, ISSN 13652095

Pavasovic, M.; Richardson, N.A.; Anderson, A.J.; Mann, D. \& Mather, P.B. (2004). Effect of $\mathrm{pH}$, temperature and diet on digestive enzyme profiles in the mud crab, Scylla serrata. Aquaculture, Vol. 242, No. 1-4, (December 2004), pp. 641-654, ISSN 00448486

Pavasovic, A.; Richardson, N.A.; Mather, P.B. \& Anderson, A.J. (2006). Influence of insoluble dietary cellulose on digestive enzyme activity, feed digestibility and survival in the red claw crayfish, Cherax quadricarinatus (von Martens). Aquaculture Research, Vol. 37, No. 1, (January 2006), pp. 25-32, ISSN 1365-2109

Pavasovic, A.; Anderson, A.J.; Mather, P.B. \& Richardson, N.A. (2007a). Effect of a variety of animal, plant, and single cell-based feed ingredients on diet digestibility and digestive enzyme activity in redclaw crayfish, Cherax quadricarinatus (Von Marten 1868). Aquaculture, Vol. 272, No. 1-4, (November 2007), pp. 564-572, ISSN 0044-8486

Pavasovic, A.; Anderson, A.J.; Mather, P.B. \& Richardson, N.A. (2007b). Influence of dietary protein on digestive enzyme activity, growth and tail muscle composition in redclaw crayfish, Cherax quadricarinatus (von Martens). Aquaculture Research, Vol. 38, No. 6, (April 2007), pp. 644-652, ISSN 1365-2109

Pearce, C.M.; Daggett, T.L. \& Robinson, S.M.C. (2002a). Effect of protein source ratio and protein concentration in prepared diets on gonad yield and quality of the green sea urchin, Strongylocentrotus droebachiensis. Aquaculture, Vol. 214, No. 1-4, (November 2002), pp. 307-332, ISSN 0044-8486 
Pearce, C.M.; Daggett, T.L. \& Robinson, S.M.C. (2002b). Effect of binder type and concentration of prepared feed stability and gonad yield and quality of the green sea urchin, Strongylocentrotus droebachiensis. Aquaculture, Vol. 205, No. 3-4, (March 2002), pp. 301-323, ISSN 0044-8486

Pearce, C.M.; Daggett, T.L. \& Robinson S.M.C. (2004). Effect of urchin size and diet on gonad yield and quality in the green sea urchin (Strongylocentrotus droebachiensis). Aquaculture, Vol. 233, No. 1-4, (April 2004), pp. 337-367, ISSN 0044-8486

Perez-Jimenez, A.; Cardenete, G.; Morales, A. E.; Garcia-Alcazar, A.; Abellan, E. \& Hidalgo, C. (2009). Digestive enzymatic profile of Dentex dentex and response to different dietary formulations. Comparative Biochemistry and Physiology - Part A: Molecular \& Integrative Physiology, Vol. 154, No. 1 (September 2009), pp 157-164, ISSN 1095-6433

Person Le Ruyet, J.P.; Alexander, J.C.; Thebaud, L. \& Mugnier, C. (1993). Marine fish larvae feeding: formulated diets or live prey? Journal of World Aquaculture Society, Vol. 24, No.2, (June 1993), pp. 211- 224, ISSN 1749-7345

Phillips, K.; Bremer, P.; Silkock, P.; Hamid, N.; Delahunty, C.; Barker, M. \& Kissick, J. (2009). Effect of gender, diet and storage time on the physical properties and the sensory quality of sea urchin (Evechinus chloroticus) gonads. Aquaculture, Vol. 288, No. 3-4, (March 2009), pp. 208-215, ISSN 0044-8486

Pratoomyot, J.; Bendiksen, E.Å; Campbell, P. J.; Jauncey, K. J.; Bell, J.G. \& Tocher, D.R. (2011). Effects of different blends of protein sources as alternatives to dietary fishmeal on growth performance and body lipid composition of Atlantic salmon (Salmo salar L.). Aquaculture, Vol. 316, No. 1-4, (June 2011), pp. 44-52, ISSN 00448486

Rivas-Vega, M.E.; Goytortúa-Bores, E.; Ezquerra-Brauer, J.M.; Salazar-García, M.G.; CruzSuárez, L.E.; Nolasco, H. \& Civera-Cerecedo, R. (2006). Nutritional value of cowpea (Vigna unguiculata L. Walp) meals as ingredients in diets for Pacific white shrimp (Litopenaeus vannamei Boone). Food Chemistry, Vol. 97, No. 1, (July 2006), pp. 41-49, ISSN 0308-8146

Robinson, J.A.J.; Kellaway, I.W. \& Marriott, C. (1975). Effects of Blending on the Rheological Properties of Gelatin Gels. Journal of Pharmacy and Pharmacology, Vol. 27, No 11, (November 1975), pp. 188-824, ISSN 0022-3573

Rodriguez, A.; Le Vay, L.; Mourente, G. \& Jones, D.A. (1994). Biochemical composition and digestive enzyme 'activity in larvae and postlarvae of Penaeus japonicus during herbivorous and carnivorous feeding, Marine Biology, Vol. 118, No. 1, (March 1994), pp. 45-51, ISSN 0025-3162

Rosas, C.; Cuzon, G.; Gaxiola, G.; Arena, L.; Lemaire, P.; Soyez, C. \& Van Wormhoudt , A. (2000). Influence of dietary carbohydrate on the metabolism of juvenile Litopenaeusstylirostris. Journal of Experimental Marine Biology and Ecology, Vol. 249, No. 2, (June 2000), pp. 181-198, ISSN 0022-0981

Rosas, C.; Tut, J.; Baeza, J.; Sanchez, A.; Sosa, V.; Pascual, C.; Arena, A.; Domingues, P. \& Cuzon, G. (2008). Effect of type of binder on growth, digestibility, and energetic balance of Octopus maya. Aquaculture, Vol. 275, No. 1-4, (March 2008) pp. 291-297, ISSN 0044-8486

Ruscoe, I.M; Jones, C.M.; Jones, P.L. \& Caley, P. (2005) The effects of various binders and moisture content on pellet stability of research diets for freshwater crayfish . Aquaculture Nutrition, Vol 11, No.2, (April 2005), pp. 87-93, ISSN 1353-5773 
Schlosser, S.C.; Lupatsch, I.; Lawrence, J.M.; Lawrence, A.L. \& Shpigel, M. (2005). Protein and energy digestibility and gonad development of the European sea urchin Paracentrotus lividus (Lamarck) fed algal and prepared diets during spring and fall. Aquaculture Research, Vol. 36, No. 10, (July 2005), pp. 972-982, ISSN 1365-2109

Seixas Filho J.T.; Rostagno, H.S.; Queiroz, A.C.; Euclydes, R.F. \& Barabarino, P. Jr. (1997a). Evaluation of the performance of post-larvae of the freshwater prawn Macrobrachium rosenbergii fed with balanced diets containing different binders. Revista Brasiliana de Zootecnia. Vol. 26, No. 4, pp. 638-644, ISSN 1806-9290

Seixas Filho J.T.; Rostagno, H.S.; Euclydes, R.F.; Queiroz, A.C. \& Barabarino, P. Jr. (1997b). Effect of binders on the hydrosolubility of balanced diets for freshwater prawns (Macrobrachium rosenbergii, de Man) in the post-larval stage. Revista Brasiliana de Zootecnia. Vol. 26, No. 4, pp. 638-644, ISSN 1806-9290

Shewry, P.R. (2009). Wheat. Journal of Experimental Botany, Vol. 60, No. 6, (April 2009) pp. 1537-53, ISSN 0022-0957

Shiau, S.Y. \& Peng, C.Y. (1992). Utilization of different carbohydrates at different dietary protein levels in grass prawn, Penaeus monodon, reared in seawater. Aquaculture, Vol. 101, No. 3-4, (February 1992), pp. 241-250, ISSN 0044-8486

Simon, C.J. (2009). The effect of carbohydrate source, inclusion level of gelatinised starch, feed binder and fishmeal particle size on the apparent digestibility of formulated diets for spiny lobster juveniles, Jasus edwardii. Aquaculture, Vol. 296, No. 3-4 , (November 2009), pp. 329-336, ISSN 0044-8486

Sinha, A.K.; Kumar, V.; Makkar, H.P.S.; De Boeck, G. \& Becker, K. (2011). Non-starch polysaccharides and their role in fish nutrition - A review Food Chemistry, Vol. 127, No. 4, (August 2011) pp. 1409-1426, ISSN 03088146

Smidsrod, O.; Haug, A. \& Larsen, B. (1966). The influence of $\mathrm{pH}$ on the rate of hydrolysis of acidic polysaccharides. Acta chemical Scandinavica, Vol. 20, No. 4, pp. 1026-1034, ISSN 0302-4377

Smith, D.M. \& Tabrett, S.J. (2004). Accurate measurement of in vivo digestibility of shrimp feeds. Aquaculture, Vol. 232, No.1-4, (April 2004), pp. 563-580, ISSN 0044-8486

Stephen, A.M. (1983). Other plant polysaccharides, In: The polysaccharides. Aspinall, G.O., pp. 97-193, Academic Press, New York

Storebakken, T. (1985). Binders in fish feeds I. Effect of alginate and guar gum on growth, digestibility, feed intake and passage through the gastrointestinal tract of rainbow trout. Aquaculture, Vol. 47, No. 1, (July 1985), pp. 11-26, ISSN 0044-8486

Storebakken, T. \& Austreng, E. (1987). Binders in fish feeds II. Effect of different alginates on the digestibility of macronutrients in rainbow trout. Aquaculture, Vol. 60, No. 2, (February 1987), pp. 121-131, ISSN 0044-8486

Storebakken, T.; Shearer, K.D. \& Roem, A.J. (1998). Availability of protein, phosphorus another elements in fish meal, soy-protein concentrate and phytase-treated soy protein-concentrate-based diets to Atlantic salmon, Salmo salar. Aquaculture, Vol. 161 No. 1-4, (February 1998), pp. 365-379, ISSN 0044-8486

Teshima. S.; Kanazawa, A. \& Sakamoto, M. (1982). Microparticulate diets for the larvae of aquatic animals. Mini review and data file of Fisheries Research, Kagoshima University 2, pp. 67-86

Usov, A I. (1998). Structure analysis of red seaweed galactan of agar and carrageenan groups. Food Hydrocolloids, Vol. 12, No 3, (July 1998), pp. 301-308, ISSN0268-005X 
Valverde, J. C.; Hernández M. D.; Aguado-Gimenez, F. \& Garciá Garciá, B. (2008). Growth, efficiency and condition of common octopus (Octopus vulgaris) fed on two formulated moist diets, Aquaculture, Vol. 275, No. 1-4, (March 2008), pp. 266-273, ISSN 0044-8486

Van der Meer, J. (2006). Metabolic theories in ecology. Trends in Ecology and Evolution. Vol. 21, No. 3, (November 2006), pp. 136-140, ISSN 0169-5347

Van Wormhoudt, A.; Cruz, E.; Guillaume, J. \& Favrel, P. (1986). Action de l'inhibiteur trypsique de soja sur lacroissance et l'activite des enzymes digestives chez' Penaeus japonicus (Crustacea, Decapoda): role ^eventuel des hormones gastro-intestinales. Oceanis, Vol. 12, pp. 305-319, ISSN 0182-0745

Volpe, M.G.; Monetta, M.; Di Stasio, M. \& Paolucci, M. (2008). Rheological behavior of polysaccharide based pellets for crayfish feeding tested on growth in the crayfish Cherax albidus. Aquaculture, Vol. 274, No. 2-4, (February 2008), pp. 339-346, ISSN 0044-8486

Volpe, M.G.; Malinconico, M.; Varricchio, E. \& Paolucci, M. (2010). Polysaccharides as biopolymers for food shelf-life extension: Recent patents. Recent Patents on Food, Nutrition \& Agriculture, Vol. 2, No. 2, (June 2010), pp. 129-139, ISSN 1876-1429

Watanabe, T. (2002). Strategies for further development of aquatic feeds. Fisheries Science, Vol. 68, No. 2, (May 2002), pp. 242-252, ISSN 1444-2906

Zhou, Q-C.; Zhou, J-B.; Chi, S-Y.; Yang, Q-H; Liu, C-W. (2007). Effect of dietary lipid level on growth performance, feed utilization and digestive enzyme of juvenile ivory shell, Babylonia areolate. Aquaculture, Vol. 272, No. 1-4 (November 2007), pp. 535-540, ISSN 0044-8486 


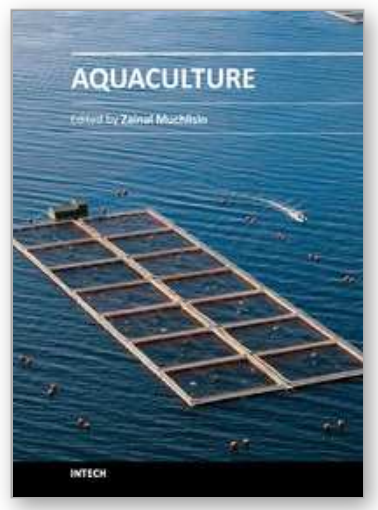

\author{
Aquaculture \\ Edited by Dr. Zainal Muchlisin
}

ISBN 978-953-307-974-5

Hard cover, 390 pages

Publisher InTech

Published online 27, January, 2012

Published in print edition January, 2012

This book provides an understanding on a large variety of aquaculture related topics. The book is organized in four sections. The first section discusses fish nutrition second section is considers the application of genetic in aquaculture; section three takes a look at current techniques for controlling lipid oxidation and melanosis in Aquaculture products. The last section is focused on culture techniques and management, ,which is the larger part of the book. The book chapters are written by leading experts in their respective areas. Therefore, I am quite confident that this book will be equally useful for students and professionals in aquaculture and biotechnology.

\title{
How to reference
}

In order to correctly reference this scholarly work, feel free to copy and paste the following:

Marina Paolucci, Adele Fabbrocini, Maria Grazia Volpe, Ettore Varricchio and Elena Coccia (2012). Development of Biopolymers as Binders for Feed for Farmed Aquatic Organisms, Aquaculture, Dr. Zainal Muchlisin (Ed.), ISBN: 978-953-307-974-5, InTech, Available from:

http://www.intechopen.com/books/aquaculture/development-of-biopolymers-as-binders-for-feed-for-farmedaquatic-organisms-

\section{INTECH}

open science | open minds

\section{InTech Europe}

University Campus STeP Ri

Slavka Krautzeka 83/A

51000 Rijeka, Croatia

Phone: +385 (51) 770447

Fax: +385 (51) 686166

www.intechopen.com

\section{InTech China}

Unit 405, Office Block, Hotel Equatorial Shanghai

No.65, Yan An Road (West), Shanghai, 200040, China

中国上海市延安西路65号上海国际贵都大饭店办公楼405单元

Phone: +86-21-62489820

Fax: +86-21-62489821 
(C) 2012 The Author(s). Licensee IntechOpen. This is an open access article distributed under the terms of the Creative Commons Attribution 3.0 License, which permits unrestricted use, distribution, and reproduction in any medium, provided the original work is properly cited. 